\title{
Measuring multidimensional poverty in the state of Minas Gerais, Brazil: looking beyond income
}

Murilo Fahel'

Leticia Ribeiro Teles ${ }^{2}$

1 Fundação João Pinheiro / School of Government, Belo Horizonte / MG — Brazil

2 Instituto Brasileiro de Mercado de Capitais (IBMEC), Belo Horizonte / MG — Brazil

The multidimensional poverty index (MPI) was developed by the Oxford Poverty \& Human Development Initiative (Ophi) in 2010. The MPI is established on indicators of health, education and standard of living. The concept of multidimensionality is anchored on the theory of poverty and human development elaborated by the indian economist Amartya Sen in the 1980s. The methodology used for the modeling of this study is based on Alkire and Foster - AF (2011) and analyzes the incidence and intensity of poverty. The purpose of this paper focuses on the application of the MPI in the state of Minas Gerais, Brazil and uses the Household Sample Survey produced by João Pinheiro Foundation (FJP) in 2009, 2011 and 2013. The results indicate that the MPI is relativaly low, 0.0329 (2009), 0.0226 (2011) and 0.0155 (2013), indicating there is a tendency for decreasing along the years.

Keywords: multidimensional poverty index; incidence; intensity; Minas Gerais; Brazil.

\section{Medindo a pobreza multidimensional do estado de Minas Gerais, Brasil: olhando para além da renda}

O índice de pobreza multidimensional (IPM) foi desenvolvido pelo Oxford Poverty \& Human Development Initiative (Ophi) em 2010. O IPM é constituído com indicadores de saúde, educação e padrão de vida. O conceito de multidimensionalidade está ancorado na teoria da pobreza e desenvolvimento humano elaborada pelo economista indiano Amartya Sem na década de 1980. A metodologia utilizada para a modelagem deste estudo baseia-se em Alkire e Foster - AF (2011) e analisa a incidência e a intensidade da pobreza. O objetivo deste trabalho centra-se na aplicação do MPI ao estado de Minas Gerais, Brasil, e utiliza a Pesquisa por Amostra de Domicílios produzida pela Fundação João Pinheiro (FJP) em 2009, 2011 e 2013. Os resultados indicam que o IPM é relativamente baixo, sendo 0,0329 (2009), 0,0226 (2011) e 0,0155 (2013), indicando que há uma tendência de redução ao longo dos anos.

Palavras-chave: índice de pobreza multidimensional; incidência; intensidade; Minas Gerais; Brasil.

\section{Medindo la pobreza multidimensional del estado de Minas Gerais, Brazil: mirando más allá de los ingresos}

El índice de pobreza multidimensional (IPM) fue desarrollado por el Oxford Poverty \& Human Development Initiatiave (Ophi) en 2010. El IPM es establecido con los indicadores de salud, educación y nivel de vida. El concepto de multidimensionalidad está anclado en la teoría de la pobreza y el desarrollo humano elaborada por el economista indio Amartya Sen, en la década de los 1980. La metodología utilizada para la modelaje deste estudio basase en Alkire y Foster - AF (2011) y analiza la incidencia y la intensidad de la pobreza. El propósito de este trabajo centrase en la aplicación del IPM en el estado de Minas Gerais, Brasil y utiliza la Encuesta de Hogares por Muestreo producida por la Fundación João Pinheiro (FJP) en 2009, 2011 y 2013. Los resultados indican que el IPM es relativamente bajo siendo 0.0329 (2009), 0.0226 (2011) y 0,0155 (2,013), lo que indica que hay una tendencia de disminución a lo largo de los años.

Palabras clave: índice de pobreza multidimensional; incidencia; intensidad; Minas Gerais; Brazil. 


\section{INTRODUCTION}

Analyzing poverty from a multidimensional perspective is relevant in Brazil given that there have been some relatively successful policies and programmes directed at overcoming poverty, which are politically and economically sustainable and do not risk being discontinued ${ }^{1}$. Realistically speaking, however, new challenges have emerged that go beyond the objectives of the pragmatic reduction of poverty: it is now crucial to promote the social mobility of the population strata with low socioeconomic levels and to work towards the discontinuation of inter-generational poverty. Thus, the uni-dimensional measurement of poverty, based solely on income, has proven to be insufficient for capturing the diverse needs of the poorest, which emerge in several dimensions, including health, education, employment, etc. According to this perspective, the configuration for measuring the multidimensionality of poverty became part of the scope of social policies in the country, with the concomitant introduction of a new agenda for social policies.

The Brasil sem Miséria programme (Brazil without Misery -2011 to $2014-1^{\text {st }}$ cicle) adopted the multidimensional concept of poverty, as a strategy to better understand the objectives proposed by social policies and, thus, reopened the debate on the need to rethink the limits of social programmes that fight poverty.

In this direction, the states of São Paulo and Minas Gerais also started using this new concept and, in particular, Minas Gerais has deepened its application in the policies embodied in the Travessia Programme ${ }^{2}$ (2007-2014). The resurgence of this approach at national and sub-national levels and considerations on its adaptability require a more careful analysis of the concept of multidimensional poverty in order to achieve maximized results in these new social programmes.

This paper provides an initial analysis of poverty and other social indicators in Latin America, Brazil and the state of Minas Gerais, highlighting the relevant changes in the last decade. The argument is that in the case of Brazil and Minas Gerais, these changes have occured in a context of important restructuring of the social protection system. The paper presents a brief review of the conceptualization and methodology on measuring multidimensional poverty and an empirical analysis of a case study of the state of Minas Gerais with measurement of incidence, intensity and multidimensional poverty index (MPI). This study includes the modeling of an MPI for 11 administrative regions of the state, as well as for urban and rural areas. In order to achieve these goals, this study used the methodology for modelling based on the global MPI proposed by Alkire and Foster (2011) and data from the 2009, 2011 and 2013 Household Sample Survey for the state of Minas Gerais (PAD-MG).

\footnotetext{
${ }^{1}$ In the 90s, cash transfer programmes were implemented in Brazil and, in 1996, the first programme was already widespread throughout the country. In 2000 and 2001, the programmes Vale Gás (Gas Voucher), Bolsa Escola (School Grant), Bolsa Alimentação (Food Grant) and Cartão Alimentação (Food Card) were created. Three years later they were unified in the Bolsa Família Programme (Family Grant). In 2011, the federal programme Brasil sem Miséria (Brazil Without Misery), which incorporated the Family Grant, was launched. From an income standpoint, the poverty among families participating in the program was eradicated. For more information, see here: $<$ http:// www.mds.gov.br/falemds/perguntas-frequentes/superacao-da-extrema-pobreza\%20>.

${ }^{2}$ The State Government of Minas Gerais in Brazil has established a state-wide poverty reduction programme called Travessia, whis focuses on multidimensional poverty and utilizes the Alkire Foster measure. To date, Travessia has implemented a Multidimensional Poverty Index (MPI) in 132 of its municipalities. The objective of the programme is to "promote social and economic inclusion of the poorest and most vulnerable populations through the articulation of territorial public policies". For more information, see here: $<$ www. ophi.org.uk/policy/national-policy/brazil-mpi/>.
} 


\section{THE CONCEPT OF MULTIDIMENSIONAL POVERTY}

The issue of poverty is a widely discussed phenomenon in the literature, but recognizing poverty as a multidimensional phenomenon is counter-hegemonic and innovative. The multidimensional measurement expands the scope of poverty analysis and constitutes an advanced and alternative mean for measuring and explaining poverty. According to Battiston and collaborators (2009, p.2), different theoretical perspectives concerned with the well-being of individuals have contributed with distinct approaches to multidimensional poverty:

In recent years, a consensus has emerged among those studying and making policies related to an individual's well-being: poverty is best understood as a multidimensional phenomenon. However, views differ among analysts regarding the relevant dimensions and their relative importance. Welfarists stress the existence of market imperfections or incompleteness and the lack of perfect correlation between relevant dimensions of well being (Atkinson, 2003; Bourguignon and Chakravarty, 2003; Duchos and Araar, 2006), wich makes the focus on a sole indicator such as income somewhat unsatisfactory. Non welfarists point to the need to move away from the space of utilities to a different and usually wider space, where multiple dimensions are both instrumentally and intrinsically important. Among the none welfarists, there are two main strands: the basic needs approach and the capability approach (Duclos and Araar, 2006). The first approach, based on Rawl's Theory of Justice, focuses on a set of primary good that are constituent elements of wellbeing and considered necessary to live a good life (Streetent el al., 1981). The second approach, championed by Sen (1992), argues that the relevant space of well-being should be the set of functionnings (or outcomes) that the individual is able to achieve. This set is referred to as the capability set "reflecting the person's freedom to lead one type of life and another" [Sen, 1992:40].

The recognized tradition of the Economic Commission for Latin America (Eclac) with the approach of Unsatisfied Basic Needs - UBN (Feres and Mancero, 2001) can be compared with the current prospect of Alkire and Foster (2011) of creating of the Multidimensional Poverty Index - MPI.

The UBN's theory of Codes (2008) is a "multifaceted approach to poverty" with two-dimensional classification requirements: i) the private household consumption such as food, shelter, clothing etc. and ii) the provision of collective services as social health, education, public transportation, sanitation and access to culture. The UBN's vision is a counterpoint to monetarist perspective based solely on insufficient income. While methods based on income or consumption individualize the poor household according to their ability to acquire all the goods and services necessary to meet their basic needs. Thus, the method of UBN defines if the domicile can effectively meet these needs by researching products actually consumed. In this way, it is considered that a unit is poor if it does not reach the threshold corresponding to gaps of basic needs (Mideplan, 2002).

The UBN method is a transfer of an individual's poverty concept to the idea of minimum resources for collective use available in local communities in their entireties, or as stated Codes (2000) "emphasizes the minimum resources required by local communities and not just survival and efficiency needs of individuals and families". Limitations and measurement complexities of multifaceted poverty present in UDN find their optimization in the MPI, for singles as the unit of analysis of home and 
create more streamlined and parsimonious measurement criteria. The MPI is based on the view of Amartya Sen (2000), which considers poverty as a multidimensional phenomenon that affects people in many ways and its measurement must observe different deprivations of individuals.

In this sense, human and social development vision extends the analysis of the phenomenon of poverty to produce a new critical and sensible approach to social reality constituting a healthy innovation, but also bringing with it conceptual and empirical challenges with induction of a new schedule directed to a broad political and institutional process of social transformation.

This paper focuses on Sen's analysis (2000), which is based on the concept of binomial poverty, and introduces parameters founded on the principles of social justice. Furthermore, Sen works with a new concept of well-being, meaning poverty is no longer restricted to the means and resources that individuals have, but rather to an individual's freedom of choice regarding his/her purpose in life. Sen's focus on poverty is based on two interrelated concepts: i) functionings, which are associated to the states and actions that individuals would like to lead their lives; and ii) capacity, which refers to whether or not a person can exercise his/her freedom of choice in relation to different paths in life.

Therefore, relevant functionings can vary from elementary things, such as being adequately nourished, being in good health, living without the fear of getting preventable diseases and of facing premature death, to more complex achievements, such as being happy, having self-respect and taking part in community life. Closely related to the concept of functionings is the concept of the capacity to make choices. This represents the various combinations of functionings (states and actions) that a person can perform. The ability, therefore, is a set of vectors of functionings, reflecting the person's freedom to lead one kind of life or another. Thus, the prospect of an innovative multidimensional approach to poverty, which focuses on the dilemmas of consensus and the complexity of how it is measured, demands innovative forms of social policy intervention. This leads to the difficult question regarding what would be the best choice to make in the face of poverty, considering that the measurement strategy is an interdependent mode of intervention and requires the diversification of policies and programmes to broaden its impact.

The novel perspective of the multidimensional approach to poverty, given the consensus of dilemmas and the complexity of its measurement, demands innovative forms of intervention of social policies. However, there is a great challenge: define the best public choice to fight against poverty. Considering that this measurement strategy is an interdependent intervention, there is a new requirement for diversification policies and programs to expand its impact.

It is important to consider the plasticity of multidimensional poverty perspective as it requires a new scope of public policy. The binomial option-opportunities induces a reconfiguration of public policies, with special attention to policies inserted in the social nature. In other words, there is an imminent demand associated with its effectiveness that social policies incorporate the multiple dimensions of development: economic, social, political, environmental and cultural to provide individuals a condition fulfilment and sustainable welfare.

The analysis of poverty in a multidimensional, contextualized and customized vision and the constituent aspects of each society with a range of its many structural dimensions can provide a comprehensive blueprint for the direction of the purposes and goals of public / social policies. Then, the main issue is the strategic role of the transition from a one-dimensional concept of poverty, eminently 
economistic yet adopted by various multilateral organizations and governments, to a multidimensional perspective focused on structuring social dimensions of human life. That is, ultimately, the simple configuration of a multidimensional diagnosis of poverty can contribute significantly to (re) design the purpose of social policies generating a structural change in its scope and coverage, as well as, changing its conception of effectiveness. Thus, there is a latent intention with this new conceptualization of poverty of generating impact on the decanonization of the process of social policies for emergency footwear assumptions in the ethics of human and sustainable development.

There is this evolution of social-institutional thinking from the 90s through the UNDP Human Development Report, which shifts the focus from poverty analysis to the focus of human development. In UNDP vision, human development is characterized by expanding choices of individual's process. From this perspective, if human development is the expansion of choices, in poverty there is a denial of elementary opportunities and most basic choices interfering with the achievement of a long, healthy and creative life (UNDP, 2010). It should be noted that the spread of this new paradigm of poverty concept has been progressively accepted in the world and the use of conceptual and measurable parameters of multidimensional poverty, as well, has influenced increasingly the design and implementation of social policies. Especially in Brazil and in the Latin American context, the expression of these trends are principally observed through the reconfiguration of the social protection systems.

\section{INCOME POVERTY IN LATIN AMERICA AND BRAZIL}

In the context of economic inequality, poverty is produced by the perspective of economic explotation implemented by the capitalist mode of production, that creates structural conditions for an unequal distribution of income. Brazil and the others Latin American countries are affected by a structurally unjust economic dynamic that concentrates wealth in the hands of few people to the detriment of the majority of the population.

According Eclac (2016:13), inequality is a historical and structural characteristic of Latin American and Caribbean societies that has been maintained and has reproduced itself even at times of growth and economic prosperity:

In recent years, inequality has fallen in a political context in which the region's governments have placed a high priority on social development goals and actively promoted redistributive and inclusive policies. In spite of that progress, high levels of inequality still exist, conspiring against development and posing a considerable barrier to the eradication of poverty, the expansion of citizenship, the exercise of rights and democratic governance.

The progress cited above was driven by a relative improvement in wage income among the lowestincome sectors due to active policies, such as the formalization of employment and real increases in the minimum wage, carried out in various countries.

In specific, the magnitude of income poverty in Latin America has decreased, though a slower pace than desired, with $27.9 \%$ (164 million) of the Latin American population living in poverty and $11.5 \%$ (68 million) in the range of extreme poverty in 2013 (graph 1). 

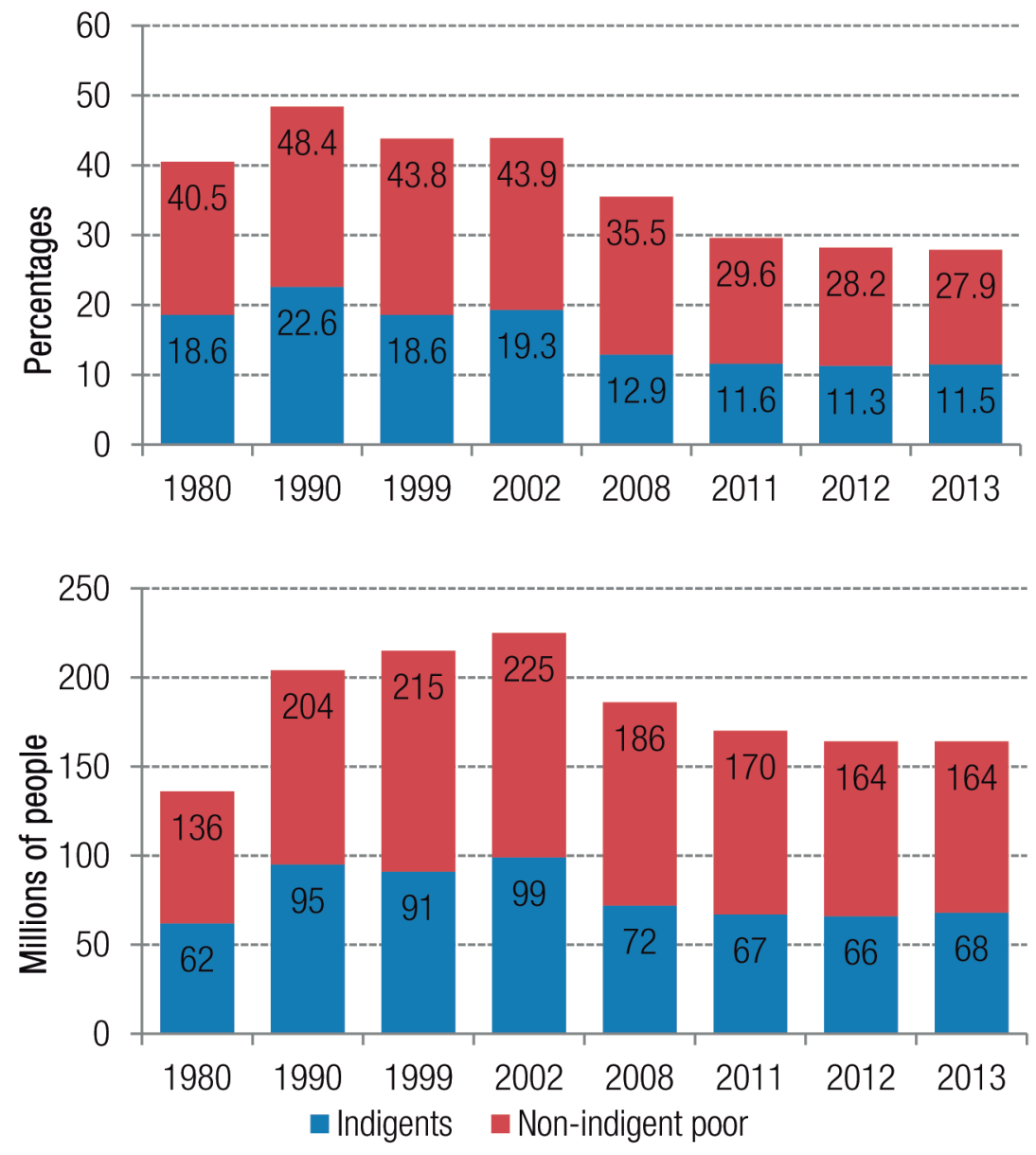

Source: Economic Commission for Latin America and the Caribbean (Eclac) on the basis of special tabulations of data from household surveys conducted in the relevant countries.

* Estimate for 18 Latin American countries and Haiti. The graph on the left presents the percentages of indigent and non-indigent poor, while the graph on the right represents the absolute numbers for the referred to populations. The 2013 figures are projections.

Obs.: Criteria of classification into indigent and non-indigent group. Indigent are those who have a family income per capita that do not cover the cost of a subsistence food basket. Non-indigent are those who have a family income per capita between once or twice the value of the cost of the basic food basket.

According to data from the Brazilian Institute of Geography and Statistical (IBGE), Brazil has a geographical area of $8,515,767 \mathrm{~km}^{2}$, with a population of 201,032,714 million (2013 estimate) and a Gross Domestic Product (GDP) of US $\$ 2,523$ trillion (2014 estimate). The country is divided into five regions (North, Northeast, Southeast, South, and Midwest), 27 states and 5,570 municipalities (figure 1). 


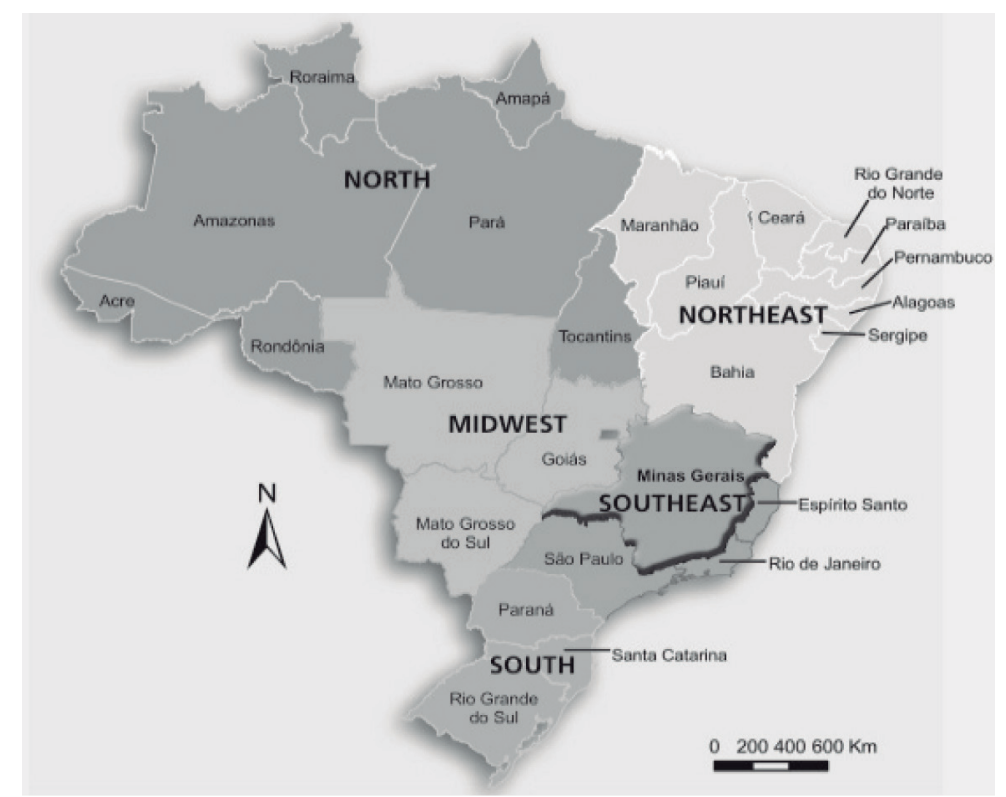

Source: Basic data from the Brazilian Geography and Statistics Institute (IBGE), 2012; IBGE Automatic Recovery System (Sidra).

Elaborated by João Pinheiro Foundation (FJP), Statistics and Information Center (CEI).

Despite Brazil's privileged income position in comparison to the world (about $80 \%$ of countries worldwide have a lower income per capita than Brazil), it continues to present a trend of very high levels of inequality in terms of income distribution and high levels of poverty. Thus, it is clear that Brazil is not a poor country, but faces the historic challenge of dealing with the malaise of social injustice, which excludes a significant portion of its population that has access only to minimal living conditions.

Brazil has accentuated social stratification among its states. The poorest areas are the north and northeast regions, while the richest regions are located in the south and southeast. The latter regions have approximately $45 \%$ of the population with the lowest percentage of poor people. Thus, it is plausible to say that there is considerable social division in Brazil as shown in figure 2, according to the incidence of income poverty (the proportion of population below US\$ 1.25 (PPP) per day) and the poverty gap ratio (intensity of poverty considering the poverty line of US\$ 1.25 (PPP) per day) in 2011.

Recently, Brazil has witnessed changes to this social situation as a result of a systematic reduction of extreme poverty as shown in figure 3. In the last decade, the government has improved the targeted social policies against extreme poverty and has achieved important results, even if they are well below the targets of the Millennium Development Goals (MDGs).

In addition to the significant advances in social policies in the last decades in the country, it is also important to highlight the contributions of macroeconomic aspects to the systematic reduction of poverty and income inequality. On the other side this policy has limitations since it increases the income of the most vulnerable population but does not contribute to the increase to the access and 
quality of basic public services such as health and education, especially in the most deprived regions of the country.

FIGURE 2 BRAZILIAN REGIONS — PROPORTION OF EXTREMELY POOR AND POVERTY GAP RATIO, 2011

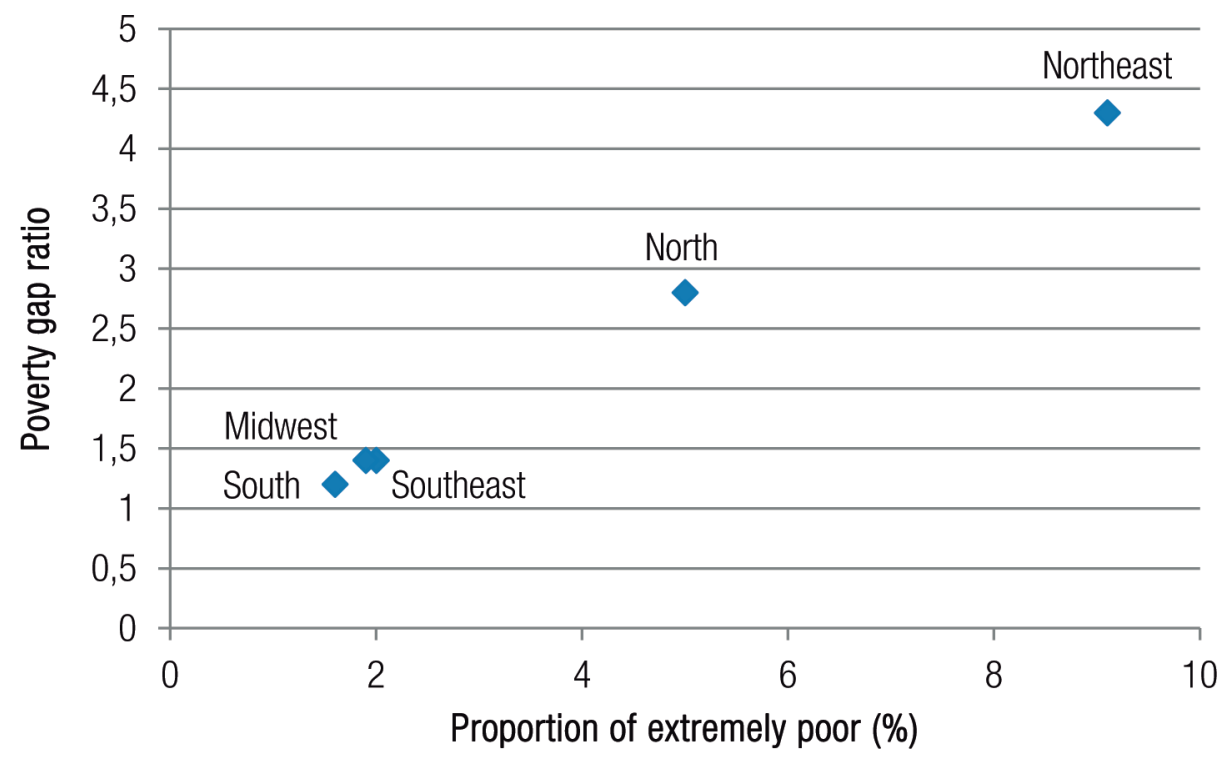

Source: Pnad (2011)

FIGURE 3 PERCENTAGE OF POPULATION WITH PER CAPITA HOUSEHOLD INCOME BELOW THE INTERNATIONAL POVERTY LINE OF US\$ 1.25 PPP / DAY

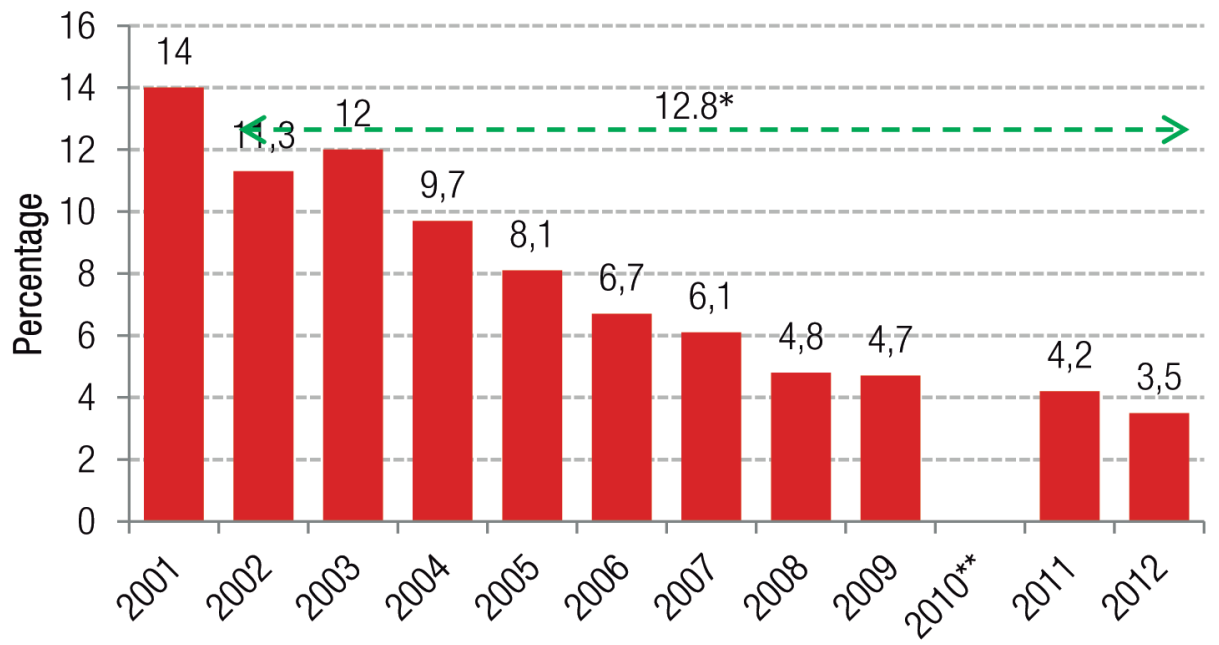

Source: Ipea (2012).

* Millennium Developments Goals - MDGs' Target

** PNAD was not collected in 2010 due to the execution of the census 
Since the Brazilian ecomomy was stabilized by the Real Plan in 1994, a tendency has been observed in the country to reduce social vulnerabilities with productive inclusion, despite the occurrence of cyclical economic crises in this period. However, if on one hand there was economic stability and control of inflation in relation to the previous period from 1985 to 1993, on the other hand, there are still persistent high levels of unemployment and, low rates of economic growth, high interest rates and even loans from the International Monetary Fund (IMF) over the period of government (1995 to 2002)

The government directly contributed to achieving the MDGs by having its social policies largely focused on such goals. Among these actions, one can cite the Bolsa Familia Programme (Family Grant), a conditional cash transfer programme that currently benefits 14 million Brazilian families, unequivocally fighting hunger and poverty and contributing to the improvement of the educational level and health status of the population (especially pregnant women and children). Other measures have been adopted to achieve the MDGs and the results have been positive. In this period of the new government (2003 to 2010) there was an increase of economic growth, a rise informal jobs with reduction of informality, a significant increase in the minimum wage above inflation as well as the resumption of public investments through the Brazilian Economic and Social Development Bank - BNDES and state-owned enterprises.

Macroeconomic trends, such as inflation control, interest rate reductions, and employment generation, regularly associated with economic growth, are determining factors for the welfare and social protection of the population, especially for the population strata with low socioeconomic levels. However, in periods when there was a clear association between economic growth and income distribution policies as well as an expansion of social protection to the most vulnerable population groups, there were virtuous cycles of falling poverty and income inequality in the country. In this sense, the generation of continuous and systematic well-being of the population is increasingly interdependent of the binomial economic development - social protection system.

\subsection{SOCIAL INDICATORS FOR BRAZIL, THE SOUTHWEST REGION AND THE STATE OF MINAS GERAIS}

Minas Gerais (figure 4) is the second most populous state (19,962,000 in 2011 and 20,590,000 in the 2013 estimate), has the third greatest GDP in the country (US\$ 159,718 billion in 2012) and is the fourth largest state by area $\left(587,000 \mathrm{~km}^{2}\right.$ ) (IBGE, 2014). Minas Gerais is located in the Southeast region of Brazil, which also contains the states of São Paulo, Rio de Janeiro and Espírito Santo (figure 1). It borders the states of Bahia (north), Goiás (northwest), Mato Grosso do Sul (far west), São Paulo and Rio de Janeiro (south), and Espírito Santo (east). The state has 853 municipalities divided into 10 administrative regions, where approximately eighty percent $(80 \%)$ of the municipalities can be considered small, having up to twenty thousand residents $(20,000)$.

In a comparative perspective, there are inequalities and similarities among Brazil, the Southeast Region and Minas Gerais (Ipea, 2011). Specifically, extreme poverty has been decreasing in Brazil and its rate is now almost below 5\%. Child Mortality has also decreased, and, the rates are above the international standard recommended from World Health Organization (WHO). The average schooling indicates rates below Argentina and Chile ${ }^{3}$ in Latin America and lags far behind the international

\footnotetext{
${ }^{3}$ The average schooling years in 2010 on Chile and Argentina according to: <http://pt.db-city.com> (accessed on: 15 Feb. 2018) were 9.8 and 9.4 respectively.
} 
standard. In the last few years, unemployment levels have gone down in Brazil, in the Southeast region and in Minas Gerais with rates below 10\%. In the case of sanitation and electricity, access is higher and closer to $100 \%$ (table 1 ).

\section{FIGURE 4 MINAS GERAIS’ ADMINISTRATIVE REGIONS}

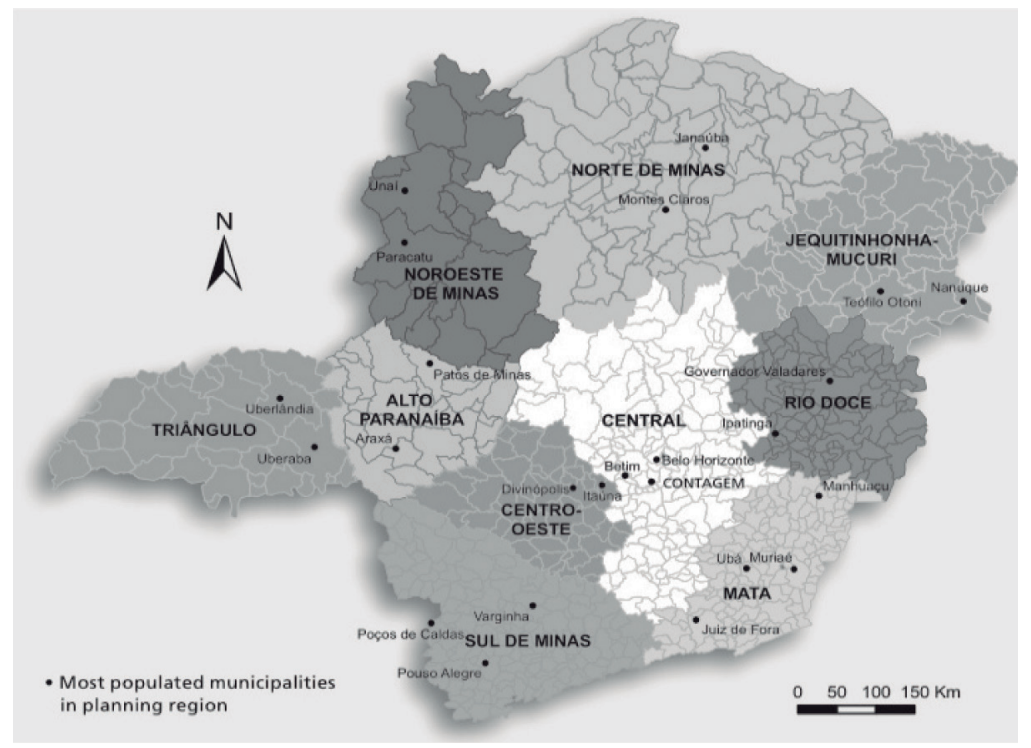

Sources: Basic data from the State Secretariat for Planning and Management (Seplag-MG), Integrated Development Plan for Minas Gerais (PMDI), and the Brazilian Geography and Statistics Institute (IBGE).

Elaborated by João Pinheiro Foundation (FJP), Statistics and Information Center (CEI).

* The map does not include the Metropolitan Region of Belo Horizonte within the Central Region.

SOCIAL INDICATORS FOR BRAZIL, THE SOUTHEAST REGION AND MINAS GERAIS FOR 2009

\begin{tabular}{llccc}
\hline Dimension & Indicators & Brazil (\%) & Southeast (\%) & Minas Gerais (\%) \\
\hline Poverty & $\begin{array}{l}\text { Extreme Poverty } \\
\text { Child Mortality (per 1,000 } \\
\text { Heath }\end{array}$ & 5.16 & 2.33 & 3.01 \\
live births) & 20.0 & 14.60 & 17.40 \\
Education & $\begin{array}{l}\text { Average Schooling Years } \\
\text { (15 years or more) }\end{array}$ & 7.55 & 8.19 & 7.36 \\
Work & Unemployment & 8.16 & 8.62 & 7.03 \\
Sanitation & Access to Drinking Water & 87.72 & 96.16 & 99.42 \\
Electricity & Access to Electricity & 98.82 & 99.80 & 99.42
\end{tabular}

Source: Ipea (2012). 


\section{THE RELEVANT CHANGES IN BRAZIL'S SOCIAL PROTECTION SYSTEM}

As a result of the promulgation of the 1988 Constitution, Brazil adopted a new paradigm of social policies based on social rights. This led to both a radical change in relation to the traditional view of social assistance established up to that moment and the implementation of several social programmes with challenging designs. Three decades later, we can observe an important reduction of poverty and a positive impact on social inequalities. Needless to say, it is worth emphasizing that the results are associated with the effects of economic growth, which has mainly taken place in the last decade.

The Social Protection System in Brazil, under the 1988 Constitution, has been expanding its coverage to the vulnerable population through the creation of policies and programmes that seek to promote greater social inclusion in the country. However, the criteria for measuring poverty was traditionally restrictive and only took into account financial aspects; a more comprehensive multidimensional approach was not applied. From 2011 onwards, through the Poverty Programme, the Brazilian government has adopted the principle of multidimensional poverty and reconfigured its eligibility criteria and portfolio of social programmes screening, leading to new challenges for the design and implementation of social policies. In the same direction and drawing on the contribution of social equity programmes, the state of Minas Gerais has implemented a series of initiatives and innovations, thus supplementing the federal programmes. Consequently, it has taken a more focused approach to the social issues of the state. This study proposes to contribute both analytically and methodologically in order to complement the administrative and managerial capacities of the national government and the state of Minas Gerais, as well as to apply and disseminate the use of MPI. The main objective here is to provide further clarifications regarding the issue at hand, so as to maximize the impact of social policies in a way that leads to the sustainable human and social development of the targeted populations.

Nowadays, there are robust institutional efforts towards the incorporation of the multidimensional analysis of poverty with the objective of implementing integrated and inter-sectoral social policies. Recently, emerging studies of multidimensional poverty have produced new forms of analysis and established a new basis for integral intervention, mainly in the area of extreme poverty. In this direction, the federal government launched the Brazil Without Misery Programme $e^{4}$ at the end of 2011 and some states, such as Minas Gerais, have adopted this strategy for a longer period with the Travessia Programme. ${ }^{5}$ While both programmes focus on multidimensional poverty, only the Minas Gerais programme uses the Global MPI from Ophi/University of Oxford/UNDP ${ }^{6}$ as a strategy to detect the situation of poor populations and to choose which types of social programmes will be adopted.

This strategy aims at the inclusion and social promotion of the poor; henceforth, the MPI has become an important instrument in the development of public policies targeted at reducing poverty in the country and state. The premise behind the use of an index to diagnose poverty is that it "is related to several other economic and social variables, and that by understanding these relationships and paths, it may be possible to formulate better policies to reduce the prevalence of poverty" (Foster, 2007:3).

\footnotetext{
${ }^{4}$ More information can be found at: $<$ www.mds.gov.br $>$.

${ }^{5}$ More information can be found at: <http://www.sedese.mg.gov.br $>$ or $<$ http://www.scribd.com/doc/66796279/Caderno-Travessia $>$.

${ }^{6}$ In 2010, the UNDP's Human Development Report by Ophi presented the MPI of Brazil: <http://hdr.undp.org/en>.
} 


\section{MEASURING MULTIDIMENSIONAL POVERTY}

In this study, the incidence, intensity and multidimensional poverty index are measured by using Alkire \& Foster's methodology (2011). The Alkire Foster (AF) method is a way of measuring multidimensional poverty and takes into consideration the different types of deprivation individuals may experience at the same time, such as lack of education or employment, poor health and living standards. These deprivation profiles are analysed to identify who is poor, and then used to construct a multidimensional index of poverty (MPI).

The most common way of measuring poverty is to calculate the percentage of the population that are poor, known as the headcount ratio $(H)$. Once this population is identified, the AF method generates a unique class of poverty measures $\left(M_{\alpha}\right)$ that goes beyond the simple headcount ratio. Three measures in this class are the most relevant:

- Adjusted headcount ratio $\left(M_{0}\right)$, also known as the MPI: this measure reflects both the incidence of poverty (the percentage of the population that are poor) and the intensity of poverty (the percentage of deprivations suffered by each person or household on average). $M_{0}$ is calculated by multiplying the incidence $(\mathrm{H})$ by the intensity (A). $M_{0}=H \times A$.

- Adjusted Poverty Gap $\left(M_{1}\right)$ : this measure reflects the incidence, intensity and depth of poverty. The depth of poverty is the average 'gap' $(G)$ between the level of deprivation poor people experience and the poverty cut-off line. $M_{1}=H \times A \times G$.

- Adjusted Squared Poverty Gap $\left(M_{2}\right)$ : this measure reflects the incidence, intensity, and depth of poverty, as well as inequality among the poor (captured by the squared gap, $S$ ). $M_{2}=H \times A \times S$.

$M_{0}$ can be calculated with ordinal as well as cardinal data, which is why it is most often used. Cardinal data are required to calculate $M_{1}$ and $M_{2}{ }^{7}$

In order to achieve the proposed goals, we will use the expertise for measuring MPI in several countries, including Brazil, which has already been developed and applied by the Ophi. The aim of this paper will be to construct the MPI of the state of Minas Gerais in order to present a more disaggregated comprehension of this index. It will rely on the Alkire and Foster (2011) methodology and data from the Minas Gerais Household Sample Survey conducted by João Pinheiro Foundation (FJP). Hence, the analysis will consider the MPI disaggregated by: i) administrative regions (Northwest, North, Rio Doce, Zona da Mata, Triângulo Mineiro, Alto Paranaíba, Midwest, Jequitinhonha/Mucuri, South, Central and Metropolitan Region of Belo Horizonte $)^{8}$ and; ii) urban/rural areas.

The methodology for the calculation of multidimensional poverty is a mean of measuring poverty by adding appropriate data that are both cardinal and ordinal, which is important since many povertyrelated variables are of an ordinal nature. This methodology stands out due to a number of desirable properties in a poverty index.

\footnotetext{
${ }^{7}$ Extract of: <http://ophi.org.uk/research/multidimensional-poverty/alkire-foster-method/>. Accessed on: 15 Feb. 2018 from Alkire Foster method.

${ }^{8}$ The geographical stratification adopted for PAD-MG 2011 is essentially the same as the 2009 edition. The metropolitan region of Belo Horizonte was included in the geographical classification of the ten administrative regions (making it eleven regions).
} 


\subsection{THE POVERTY CUTOFF (IDENTIFICATION OF THE MPI POOR) ${ }^{9}$}

Each person is assigned a deprivation score according to his or her deprivations in the component indicators. The deprivation score for each person is calculated by taking a weighted sum of the deprivations experienced, so that the deprivation score for each person lies between 0 and 1 . In other words, it looks at whether a person lies between $0 \%$ and $100 \%$. Once this is calculated, a person is identified as poor if he/she is deprived in $\mathrm{x} \%$ of weighted indicators. The score increases as the number of deprivations of the person increases. In addition, the score reaches its maximum of 1 when the person is deprived in all ten indicators. A person, who is not deprived in any indicator, receives a score equal to 0 . Formally:

$$
c_{i}=w_{i} I_{1}+w_{2} I_{2}+\ldots+w_{d} I_{d}
$$

where $I_{i}=1$ if the household is deprived in indicator $i$ and $I_{i}=0$ otherwise, and $w_{i}$ is the weight attached to indicator $i$ with $\sum_{\mathrm{i}=1}^{\mathrm{d}} w_{i}=1 .^{10}$

A second cutoff or threshold is used to identify the multidimensional poor, which in the AlkireFoster methodology is called the poverty cutoff. The poverty cutoff is the share of (weighted) deprivations a household must have in order to be considered poor, and we denote it by $k .{ }^{11}$ Someone is considered poor if his/her deprivation score is equal to or greater than the poverty cutoff, that is, if $c_{i} \geq k$. In the Global MPI, a person is identified as poor if he or she has a deprivation score higher than or equal to $1 / 3$. In other words, a person's deprivation must be at least a third of the (weighted) indicators to be considered MPI poor. ${ }^{12}$ For those whose deprivation score is below the poverty cutoff, even if it is non-zero, their score is replaced by a ' 0 ' and any existing deprivations are not considered in the 'censored headcounts'. We refer to this important step as censoring the deprivations of the nonpoor (see Alkire and Foster 2011, Alkire Foster and Santos, 2011). In order to differentiate the original deprivation score from the censored one, we use the notation $c_{i}(k)$ for the censored deprivation score. Note that when $c_{i} \geq k$, then $c_{i}(k)=c_{i}$, but if $c_{i}<k$, then $c_{i}(k)=0 . c_{i}(k)$ is the deprivation score of the poor.

\subsection{COMPUTING THE MPI (AGGREGATION)}

Following the structure of Alkire and Foster's (2011) Adjusted Headcount $\left(M_{0}\right)$ measure, the MPI combines two key pieces of information: (1) the proportion or incidence of people (within a given population) whose share of weighted deprivations is $k$ or more and (2) the intensity of their deprivation,

\footnotetext{
${ }^{9}$ Extract of: <www.ophi.org.uk/wp-content/uploads/MPI_2011_Methodology_Note_4-112011_1500.pdf?79d835 in 10/05/2014> from Multidimensional Poverty Index 2011: brief methodological note. Authors: Sabina Alkire, José Manuel Roche, Maria Emma Santos and Suman Seth.

${ }^{10}$ Note that in the notation of this methodological note, the indicators' weights add up to one. This differs from the notation used in Alkire and Foster (2011), where the indicators' weights add up to the total number of indicators considered, there denoted d. However, the identification step here is equivalent to the original paper.

${ }^{11}$ Again, this notation differs from Alkire and Foster's papers (2011), where $k$ is defined as the number of deprivations someone must experience in order to be considered poor. The notation is consistent throughout this methodological note and equivalent to the original paper.

${ }^{12}$ Households with a deprivation score between $1 / 5$ and $1 / 3$ are denoted 'vulnerable' due to their proximity to the poverty cutoff.
} 
which refers to the average proportion of (weighted) deprivations they experience. Formally, the first component is called the multidimensional headcount ratio $(H)$ :

$$
\mathrm{H}=\frac{\mathrm{q}}{\mathrm{n}}
$$

Here $q$ is the number of people who are multidimensional poor and $n$ is the total population. The second component is called the intensity (or breadth) of poverty $(A)$. It is the average deprivation score of multidimensionally poor people and can be expressed as:

$$
A=\frac{\sum_{i=1}^{n} c_{i}(k)}{q}
$$

where $c_{i}(k)$ is the censored deprivation score of individual $i$ and $q$ is the number of people who are multidimensionally poor ${ }^{13}$. The MPI is the product of both:

$$
M_{0}=H \times A
$$

Another attractive feature of this method is the possibility of creating decomposition indexes that are calculated in a specific manner. For example, given that poverty is evaluated for each individual separately and then added, it is possible to disaggregate the index by location. Moreover, it is possible to disaggregate this figure by geographical areas: states, regions, urban/rural etc. As a result, we can then assess how many people are deprived in that particular aspect separately. As Alkire and Santos (2011:9) explain, "the methodology of Alkire and Foster does not specify dimensions, indicators, runs, weights or cuts, it is flexible and can adapt to various contexts. The Global MPI, in contrast, has dimensions, indicators, weights and specific cuts."

\subsection{DIMENSIONS AND INDICATORS}

The MPI is based on Amartya Sen's (2000) perspective, which considers poverty as a multidimensional phenomenon that affects people in many ways; measuring poverty should investigate different deprivations experienced by individuals. Thus, the Global MPI measures the phenomenon of poverty according to three dimensions - education, health and standard of living — and ten indicators, which are shown below in figure 5. Each dimension is equally weighted. Each indicator within a dimension is also equally weighted and these weights are shown in brackets in the diagram. In other words, this index presents an analytical capacity that "reflects the hardships of people in very rudimentary services and basic human needs in 104 countries" (Alkire and Santos, 2010:7) from a comparative perspective.

\footnotetext{
${ }^{13}$ Note that the formula of $A$ differs from Alkire and Foster (2011) in that it does not contain the number of indicators $d$ in its denominator. This is because $d$ is already included in the deprivation score $c_{i}(k)$, since it is a weighted sum of the deprivations of each poor person, where the indicators' weights add up to 1 .
} 


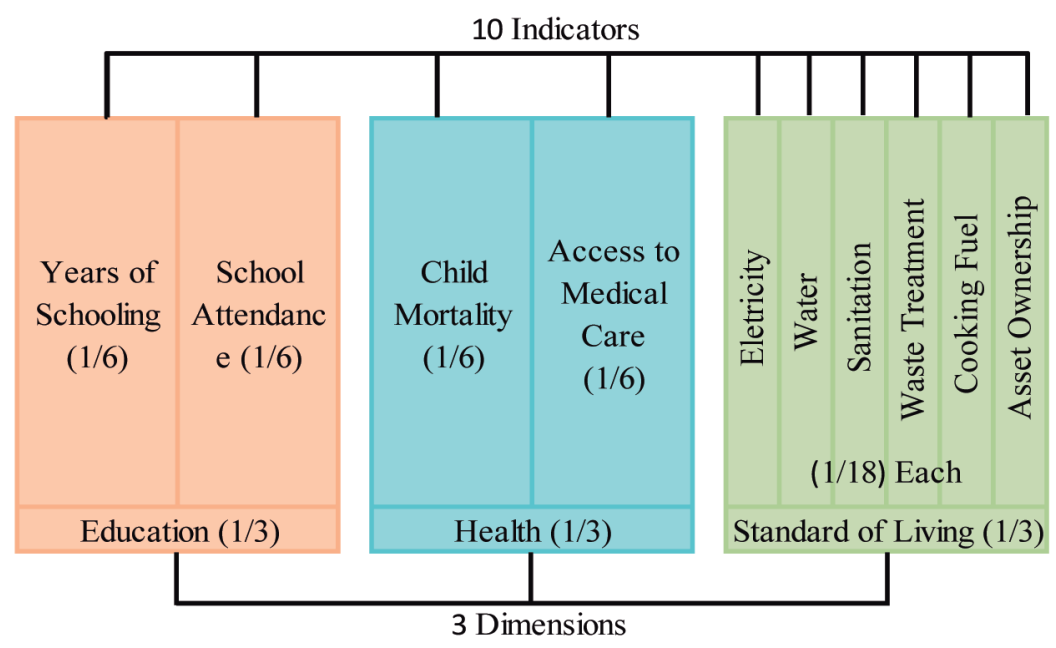

Source: <www.ophi.org.uk>.

This methodology proves to be interesting given its flexibility and capacity to be adapted to different cultural and national contexts. For example, Mexico, Colombia, Bhutan and the Philipines have adopted official multidimensional poverty measures and each one has been adapted to that country's specific cultural and political context. It also enables a comparative perspective and analysis that can be broken down into territories or geographic regions in order to indicate where and why the population is poor. It allows for the decomposition by indicators and has an easy and consistent statistical method, among several other advantages.

\subsection{DATABASE AND VARIABLES}

The data used for MPI modelling are from FJP's Household Sample Survey for the state of Minas Gerais, collected in 2009, 2011 and 2013 in partnership with the World Bank. The strategic purpose of the production of such social information is to strengthen the social and economic development of the state. In this sense, having in depth information about the population, as well as their characteristics, actions, and positions in the system of social stratification and the market, is crucial for the development, monitoring and evaluation of public policies, which, in turn, increasingly improves the process of allocating public resources (Minas Gerais, 2009).

The research sample consisted of 18,000 households in 308 municipalities of Minas Gerais and is representative of the following extracts: urban vs. rural; Belo Horizonte Metropolitan Region vs. number of metropolitan areas; Belo Horizonte vs. other municipalities; administrative regions and mesoregions. The information was distributed in the full wing sections: Section A_ Household; Section B_ Resident profile; Section C_ Education; Section D_ Health; Session E_ Work; Section F _ Incomes; Section G_ Individual Spending; and Section K_ Youth ${ }^{14}$.

\footnotetext{
${ }^{14}$ More information can be found at: <www.fjp.mg.gov.br/index.php/pesquisa-de-amostra-por-domicilios $>$.
} 
The definition of dimensions, indicators, criteria of deprivation and weights attributed to the MPI for the state of Minas Gerais are similar to the methodology adopted by Alkire and Foster (2011). For this study, however, some adjustments were made in relation to the criteria and indicators of deprivation (e.g. proxies), due to the database's specific characteristics or the need for adapting it to the current pattern of deprivation found in the Minas Gerais population (table 2).

\section{TABLE 2 DIMENSION, INDICATORS, CRITERIA OF DEPRIVATION AND WEIGHT}

\begin{tabular}{|c|c|c|c|}
\hline Dimension & Indicator & Who is Deprived? & Weight \\
\hline \multirow{2}{*}{ Education } & Years of Schooling* & $\begin{array}{l}\text { Household }(\mathrm{HH}) \text { where no member has completed elementary } \\
\text { school (i.e. nine years of schooling) }\end{array}$ & $16.7 \%$ \\
\hline & School Attendance* & $\begin{array}{l}\text { HH with at least one child between six and } 17 \text { not attending } \\
\text { school }\end{array}$ & $16.7 \%$ \\
\hline \multirow[b]{2}{*}{ Health } & Child Mortality* & HH with at least with one child up to five who has deceased & $16.7 \%$ \\
\hline & $\begin{array}{l}\text { Access to Medical Care* } \\
\text { (Nutrition) }\end{array}$ & $\begin{array}{l}\text { HH with at least one member who has needed medical attention } \\
\text { and was not attended by appropriate professional or was not } \\
\text { attended due to the difficult access to health services, in the last } \\
\text { month. }\end{array}$ & $16.7 \%$ \\
\hline \multirow{6}{*}{$\begin{array}{l}\text { Standard of } \\
\text { Living }\end{array}$} & Electricity & HH without electricity & $5.6 \%$ \\
\hline & Water & $\begin{array}{l}\text { HH does not have running water in at least one room or the water } \\
\text { does not come from a cistern or natural springs. }\end{array}$ & $5.6 \%$ \\
\hline & Sanitation* & $\begin{array}{l}\text { HH with a toilet that is not connected to the sewage collection } \\
\text { network (e.g. rudimentary sewage) or with a toilet that is shared. }\end{array}$ & $5.6 \%$ \\
\hline & $\begin{array}{l}\text { Waste Treatment* } \\
\text { (Floor) }\end{array}$ & $\begin{array}{l}\text { HH does not have waste treatment (e.g. garbage is burned or } \\
\text { thrown in the river) }\end{array}$ & $5.6 \%$ \\
\hline & Cooking Fuel & HH that cooks with wood, charcoal or dung & $5.6 \%$ \\
\hline & Asset Ownership* & $\begin{array}{l}\text { HH that owns three or fewer of the following assets — radio, TV, } \\
\text { telephone, refrigerator, stove, computer, bicycle or motorcycle - } \\
\text { and does not own a car or tractor }\end{array}$ & $5,6 \%$ \\
\hline
\end{tabular}

Source: Minas Gerais Household Sample Survey (2009, 2011, 2013).

* Re-categorization of original variables and the use of proxies to substitute for variables not found in our data base. Obs.: For more details about the conceptual definition of indicators, see annex 1.

The MPI calculation simplifies and operationalizes a multifaceted analysis of poverty, since a household is considered poor if its set of deprivations amounts to or exceeds $33 \%$ of the total. The systematization, processing and data analysis for the choice of dimensions and indicators are important 
methodological steps toward the proper calibration of the MPI and should be performed with the use of statistical software such as SPSS and Stata.

\section{RESULTS AND DISCUSSION}

The initial purpose of this study is to conduct an analysis of the MPI in the state of Minas Gerais. The objective is to reach a breakdown analysis of multidimensional poverty in regions and urban/ rural areas. Minas Gerais has 12 administrative (planning) regions ${ }^{15}$ where the government applies public policies according to the demands and needs of the population. Among these regions and the urban/rural areas, there are significant social differences, hence these analysis could help direct specific social policies.

The main results for 2009 indicate that the proportion of the poor population is $8.33 \%$ with a significant intensity of $39.94 \%$. In other words, Minas Gerais had, according to these results, around 1.65 million multidimensional poor people in 2009. ${ }^{16}$ The MPI of Minas Gerais (MG_MPI) observed within the scale of 0 to 1 is 0.032 or $3.2 \%$, which is relatively low (figure 6). For $2011,{ }^{17}$ the results are better with an incidence of $6.06 \%(H)$, with approximately 1.21 million people (440,000 fewer people than 2009), an intensity of $37.37 \%(A)$ and an MG_MPI of 0.023 or $2.3 \%$. For 2013 the results are even better, with an incidence of $4.25 \%$, intensity of $36.42 \%$ and an MPI of 0.0155 . Thus, there is significant poverty in Minas Gerais, but the trend moves towards reduction. Nevertheless, the most important change is in the incidence (proportion), which positively interferes in the results of the MPI. The intensity of poverty has also reduced from 2009 to 2011, which leads to an additional improvement of the MPI.

FIGURE 6 INCIDENCE (H), INTENSITY (A) AND MPI OF THE STATE OF MINAS GERAIS

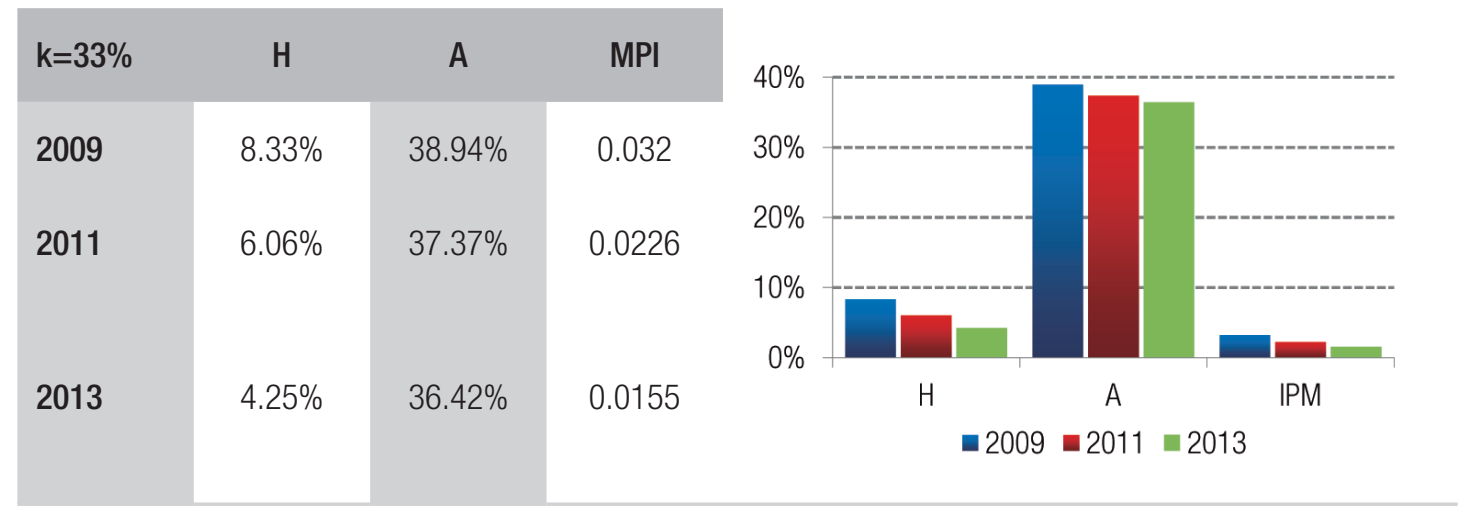

Source: PAD-MG $(2009,2011,2013)$.

\footnotetext{
${ }^{15}$ The Central region includes the Metropolitan Region of Belo Horizonte (MRBH). However, the MRBH was separated in the current division of administrative regions, and the PAD-MG (2009 and 2011) takes this into account. Furthermore, in the sample stratification of the PAD-MG, the Jequintinhonha Valley and Mucuri Valley are analyzed together. Combining these two regions is not problematic, since both have similar social indicators.

${ }^{16}$ The study chose 2010 as the reference year since it had a more precise measurement than the estimated data from 2009. Thus, the resident population of the state of Minas Gerais was 19,853,322 million (IBGE, 2014).

${ }^{17}$ For 2011, the population of Minas was 19.962 .000 million (IBGE, 2014). Available at: <http://pt.db-city.com/Pa\%C3\%ADs-M\%C3\%A9dia-de-anos-de-escolaridade>.
} 
For a better calibration of the MPI, it is important to understand the contribution of each dimension and indicator in overall poverty. Thus, we observe in figure 7 that the years of schooling have added around $40 \%$ in the three years of analysis. This indicator is the one that most contributes to the multidimensional poverty in Minas Gerais. Together the two indicators related to education (years of schooling and school attendance) contribute to over half of the MPI (53.5\%, 56.62\% and 61.56\% in 2009, 2011 and 2013, respectively). Therefore, these specific deprivations illustrate the relevance of actions in the field of education. Between 2009 and 2011, the relative contribution of the indicator School Attendance and Access to Medical Care increased, while the other indicators remained almost stable or have shown a slight reduction. From 2011 to 2013, the relative contribution of Electricity showed a strong increase and the relative contribution of the indicators Access to Medical Care and Cooking Fuel decreased considerably, while the other indicators' relative contribution have not shown expressive variations.

\section{FIGURE 7 RELATIVE CONTRIBUTION OF INDICATORS FOR MPI}
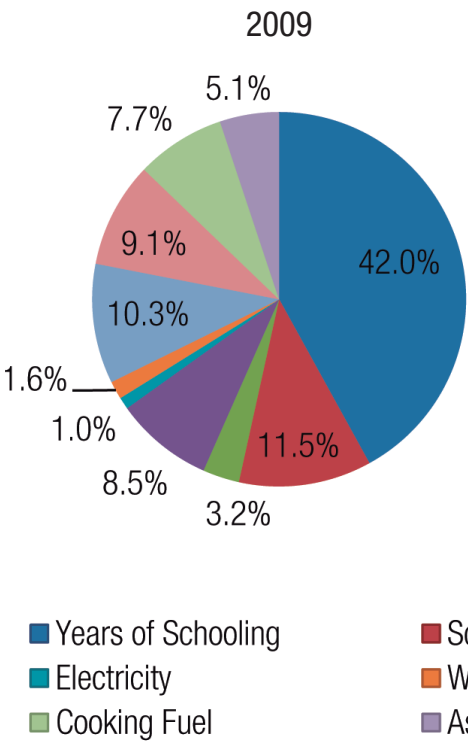
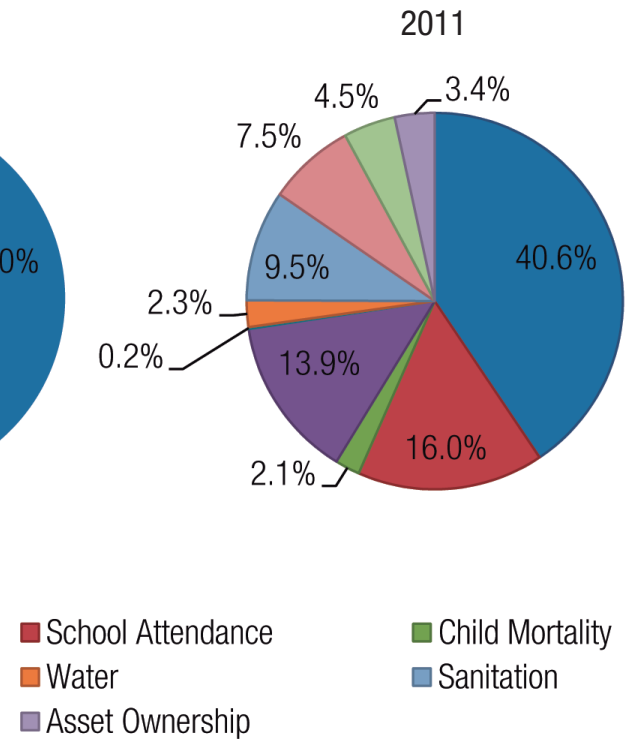

$\square$ Child Mortality $\square$ Sanitation
2013

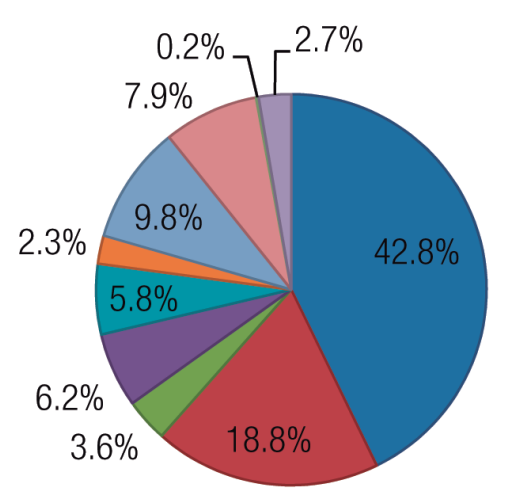

Access to Medical Care $\square$ Waste Treatment

Source: PAD-MG $(2009,2011,2013)$.

Figure 8 illustrates the breakdown (disaggregation) of multidimensional poverty by administrative regions in Minas Gerais. The higher indexes of poverty in 2009 are in Rio Doce, North and Jequitinhonha/ Vale do Mucuri regions. For 2013, the higher indexes are in the Northwest, Jequitinhonha/Vale do Mucuri, Central and Zona da Mata regions. However, the results show a systematic and generalized reduction of multidimensional poverty in Minas Gerais between 2009 to 2013 in terms of incidence $(H)$, intensity $(A)$ and index $\left(M G \_M P I\right)$, corroborating with the important trend of overcoming extreme poverty in Minas Gerais.

The change of MG_MPI showed in figure 8 is mainly due to the reduction in the proportion of poverty $(H)$. Figure 9 shows that whereas the intensity $(A)$ remains practically unchanged, the proportion $(H)$ decreases considerably. Furthermore, one can also observe (figure 11) that poorer regions have had the most significant improvements, leading to a better overall result and less discrepancy between administrative regions in the 2013 MPI. 
RAP | The transformative capacity of the Brazilian federal government in building a social welfare bureaucracy in the municipalities

\section{FIGURE 8 MPI BY ADMINISTRATIVE REGIONS IN THE STATE OF MINAS GERAIS}

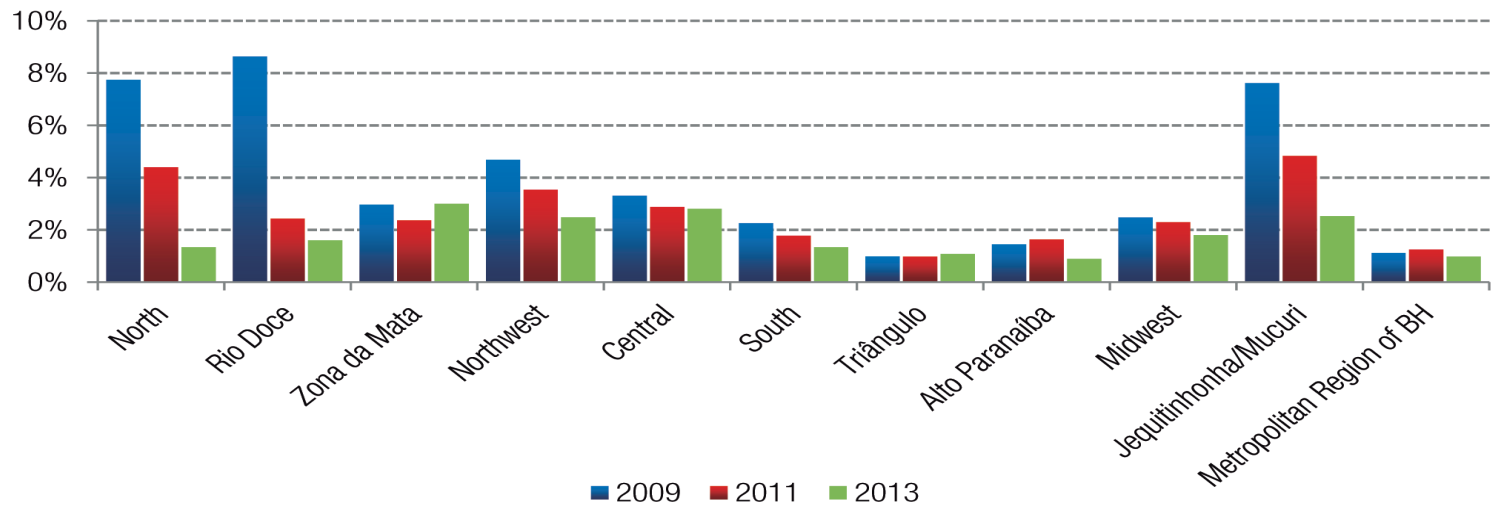

Source: PAD-MG $(2009,2011,2013)$.

FIGURE 9 THE INCIDENCE, INTENSITY AND MPI BY ADMINISTRATIVE REGIONS IN THE STATE OF MINAS GERAIS
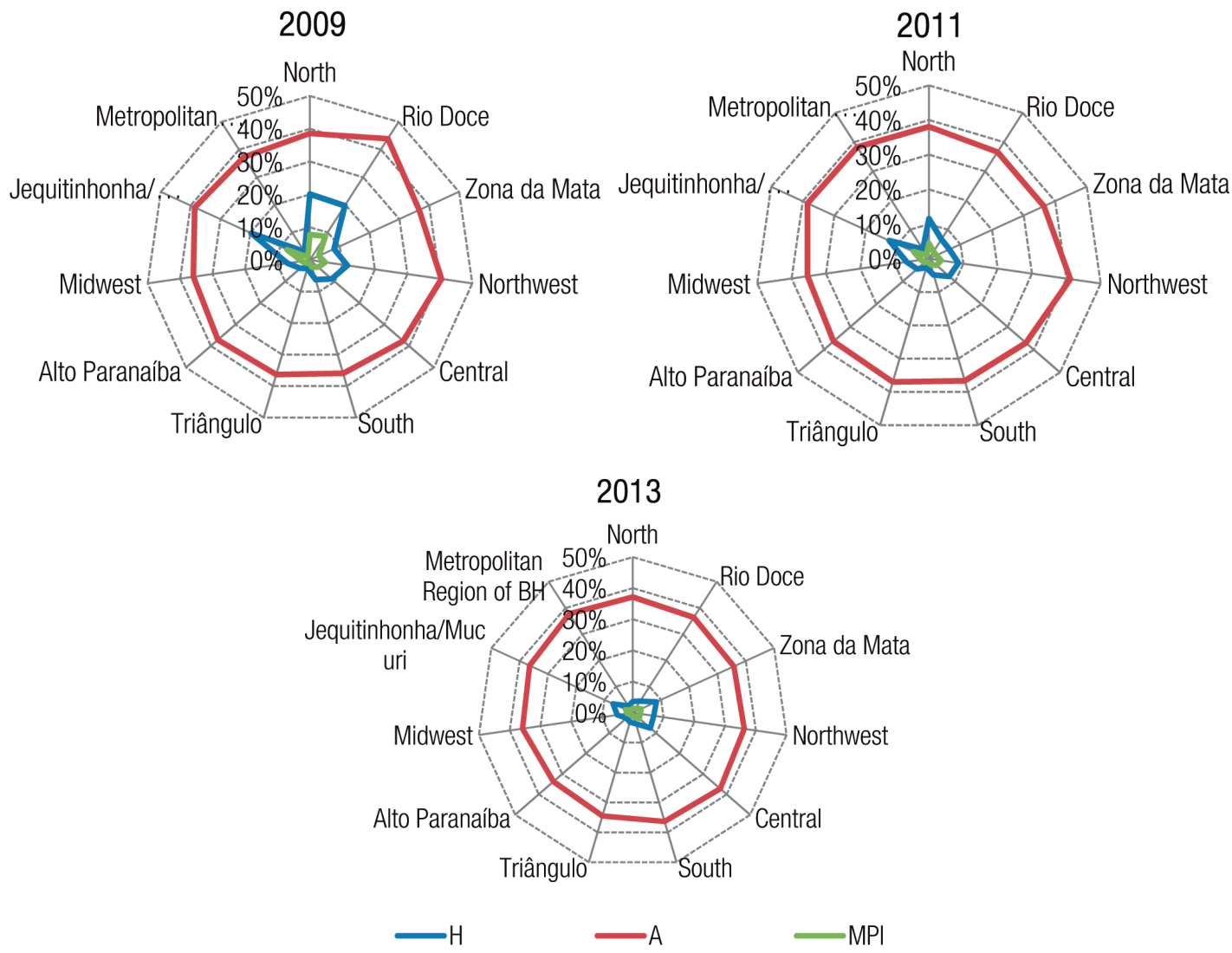

Source: PAD-MG $(2009,2011,2013)$. 
The results obtained by the MPI approach are similar to the data and results of Minas Gerais' Human Development Index. The state is divided between multidimensionally rich and poor regions. Spatial visualizations of the results are shown in figure 10, capturing the social contrasts between administrative regions and highlighting which were the main changes achieved between 2009 and 2013. Areas with more intense colors represent the regions with the most critical situation of multidimensional poverty.

FIGURE 10 MULTIDIMENSIONAL POVERTY BY ADMINISTRATIVE REGIONS

2009

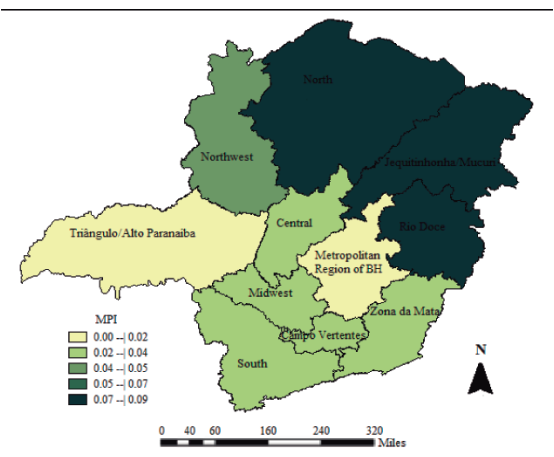

Source: PAD-MG $(2009,2011,2013)$.
2011

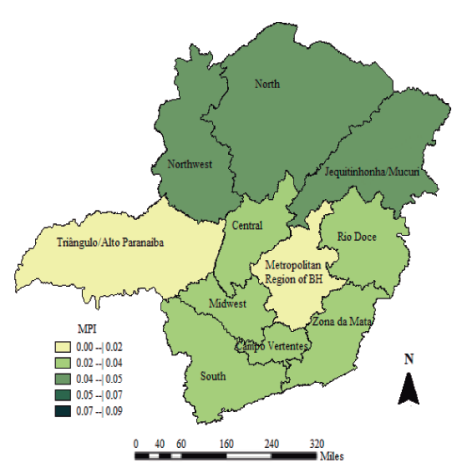

2013

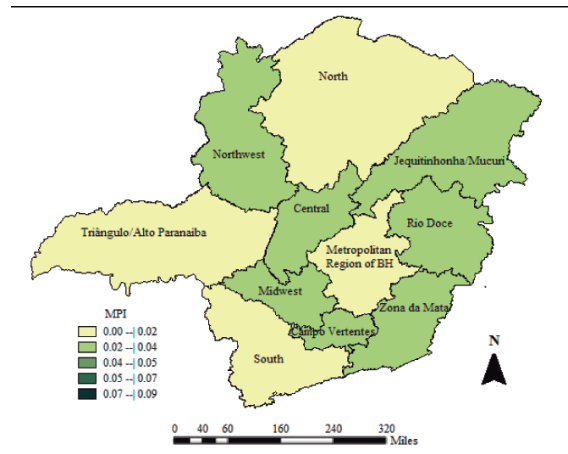

Clearly, the disagregated MPI results show significant variations between the incidence, intensity and index of multidimensional poverty; they indicate which regions are a priority and which ones require a better implementation of guided social policies in order to maximize results.

Figure 11 illustrates the relation between intensity and incidence by regions. It is possible to identify the position of each region, as well as the change in their positions from 2009 to 2013 . As noted earlier, the regions tend to be less scattered. What positively stands out is the change in the Rio Doce region, that significantly reduced both the incidence and intensity. Another aspect that also stands out, though negatively, is the Zona da Mata and Triângulo Mineiro regions, that presented a less significant change among the poorest regions. These are good examples that show how the trend of multidimensional poverty can change rapidly over time.

These changes depend on the social policies' path and focus. One of the most important impacts, in terms of incidence of multidimensional poverty reduction, was related to the effects of cash transfer programmes. The cash transfer programmes in Brazil and, consequently, in Minas Gerais have a strong focus on the poorest regions such as Rio Doce, and the impact of large-scale distribution directly affects this population. It is estimated that, from 2001 to 2011 , the income of the poorest $10 \%$ increased $550 \%$ more than the income of the richest 10\% (Ipea, 2012). This scenario represents substantial progress concerning inequality. It was an important determinant of poverty reduction in the country and was mainly due to the expansion of social assistance transfers such as the Bolsa Família Programme (Family Grant). Such programmes are effective in combating poverty and inequality because they help improve the population's access to education and health and encourage professional qualification, resulting in greater access to the labor market. Thus, coupled with economic growth and other factors 
such as the real minimum wage increase, the cash transfer programmes have played a key role in the fight against extreme poverty (Campello and Neri, 2013).

FIGURE 11 INTENSITY (A) VS. INCIDENCE (H) BY REGIONS*

2009

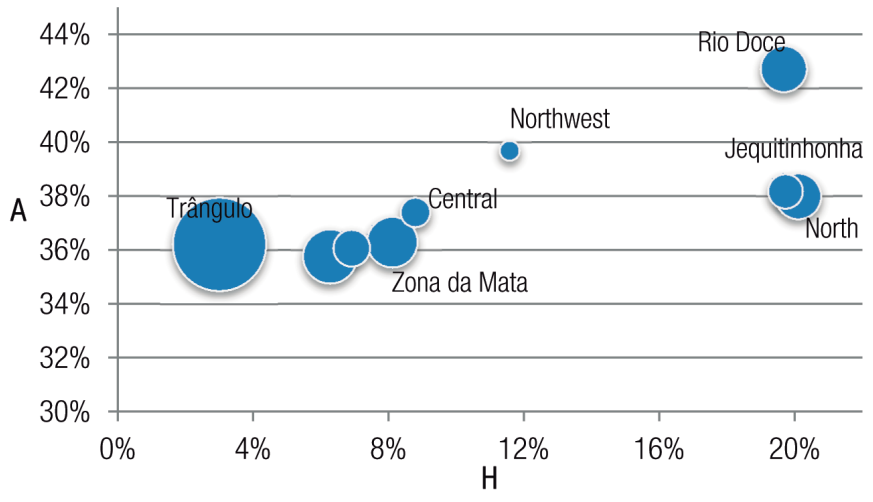

2011

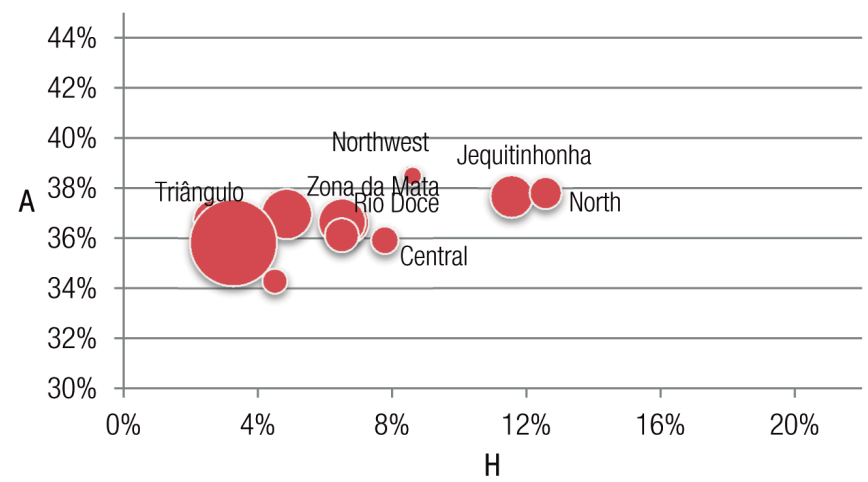

2013

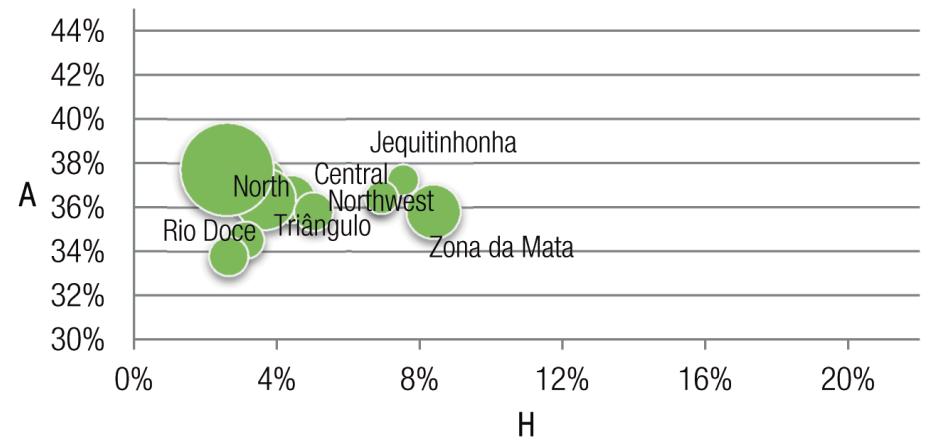

Source: PAD-MG $(2009,2011,2013)$.

* The size of the circles is proportional to the population share of the region. 
As figure 12 shows, with the decomposition of indicators and the identification of their relative contribution to the formation of multidimensional poverty, it is possible to identify by administrative regions which areas have a greater urgency and demand for public investment.

When decomposing by administrative regions in order to identify the region's relative contribution to MPI, one observes a strong contribution to the index for Years of Schooling, followed by School Attendance and Access to Medical Care. Another relevant point is that the relative contribution of the indicators represents few changes between regions, indicating, that in most cases, the regions face similar social challenges (figure 12). It is important to highlight that in the poorest regions (e.g. Jequitinhonha/Mucuri and North), the relative participation of more basic services, such as sanitation and waste treatment, are greater. Initially, there is the need for strengthening social policies directed at education, with an emphasis on improving care, academic achievement and the quality of education. At a later stage, investing in actions that improve access to health care and waste treatment would result in a more significant improvement of the population's quality of life in Minas Gerais. These challenges should influence the design and implementation of social policies, so that they become more effective and innovative in terms of targeting problems and contributing to more rapid changes in the poorer population's well-being.

It should be noted that the Travessia Programme (2007 to 2014), which is Minas Gerais' most important progamme for promoting social and productive inclusion of the poor and socially vulnerable population, is already guided by MPI. The main difference of the programme is the project Porta a Porta (Door to Door), which uses the household as the unit of analysis and points out the needs of each family; therefore, identifying deprivation in municipalities and communities that would be invisible to the analysis of other indicators. The Triângulo Mineiro, for example, is considered a region with a good level of development, but there are also some cities with unacceptable levels of poverty. With this Project and the MPI, it is possible to identify deprivations in these locations.

In comparative terms, multidimensional poverty has distinct and different characteristics when looking at the state's urban and rural areas. All results are worse in rural areas than in urban areas (figure 13). This is compatible with other indicators and indices and reinforces the already widely held belief that the strengthening of government policies in rural areas is fundamental for decreasing poverty.

The current government (2015 to 2018) has been showing a constant investment and institutional continuity in terms of social policies to combat poverty. In this sense, the Multidimensional Rural Poverty Diagnosis can be applied to 229 municipalities in the state of Minas Gerais, with the objective of identifying the rural poverty in the municipalities of the north territories, Mucuri, High, Middle and Lower Jequitinhonha and Rio Doce Valley to define the target public of the State Department of Social Development - Sedese. It can also be used to elaborate the Jequitinhonha Valley Development Plan (PDVJ) focusing on the most vulnerable areas of Minas Gerais and overcoming the levels of deprivation on resident population. The objective of the PDVJ is to implement strategies and actions to guide the Government of State aiming at the development of the High and Middle / Lower Jequitinhonha territories. This region comprises 59 municipalities consisting of a population of 770 thousand people with $38 \%$ residing in rural areas and an economy corresponding only to $1.3 \%$ of the State's GDP. 

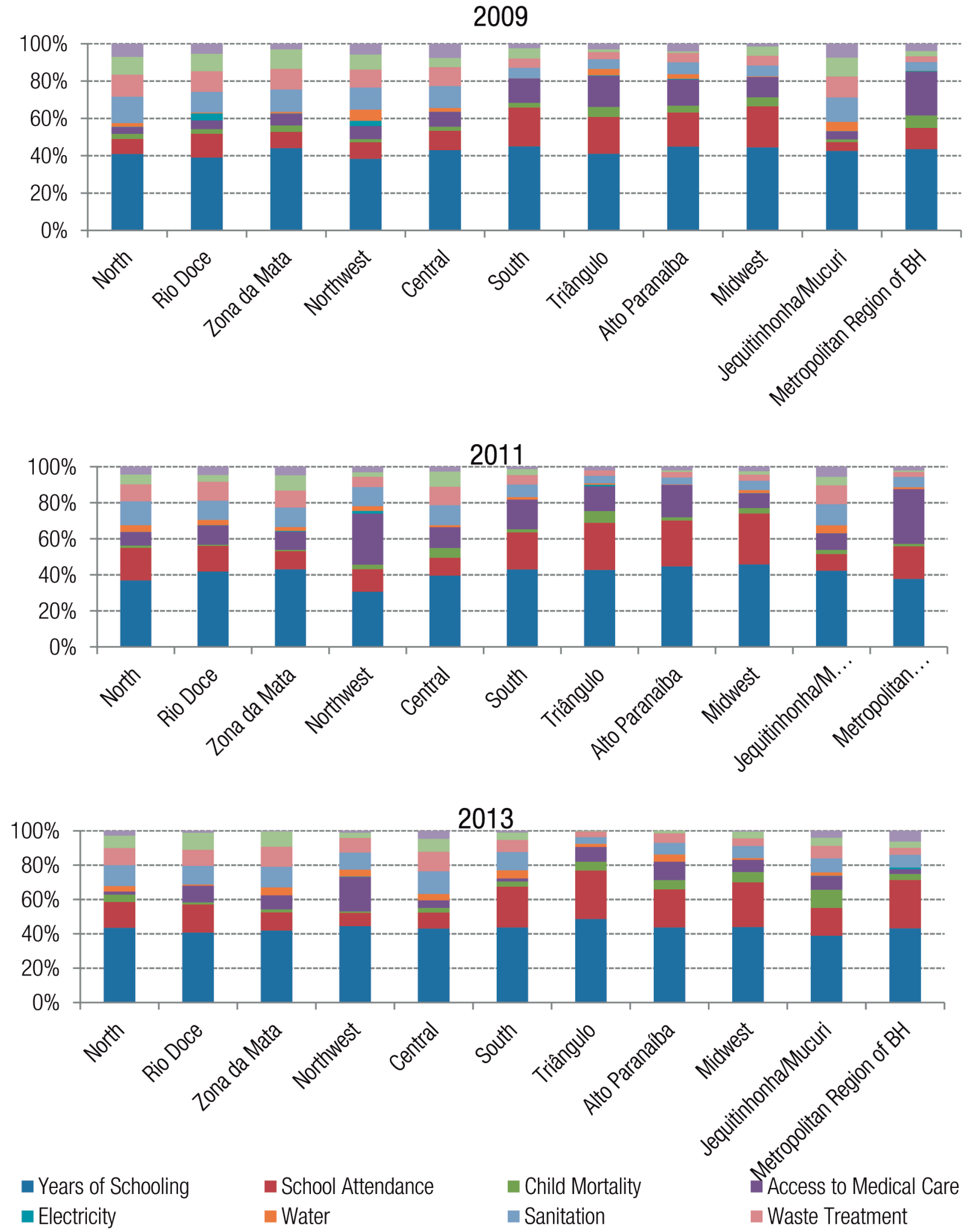

Source: PAD-MG $(2009,2011,2013)$. 


\section{9}

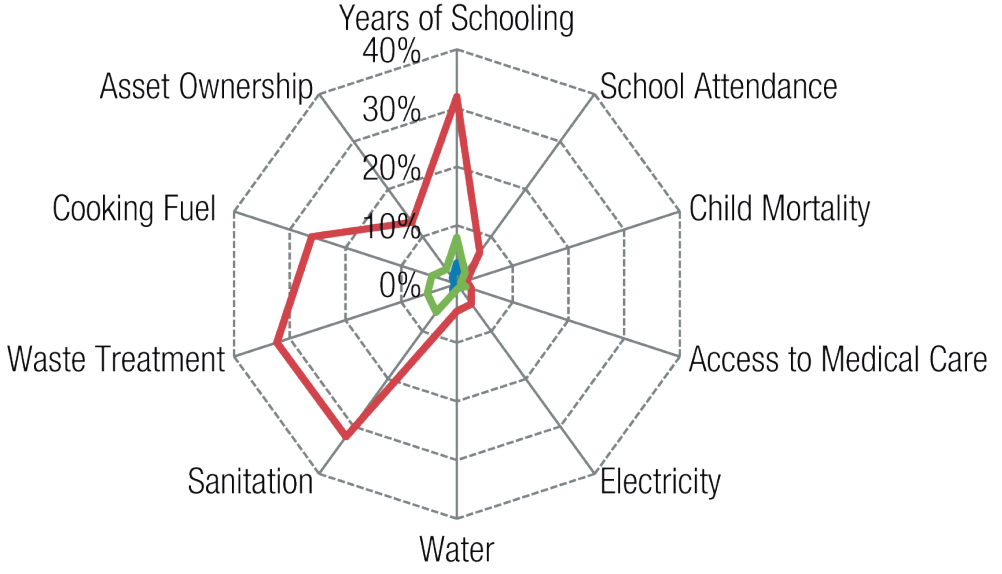

2011

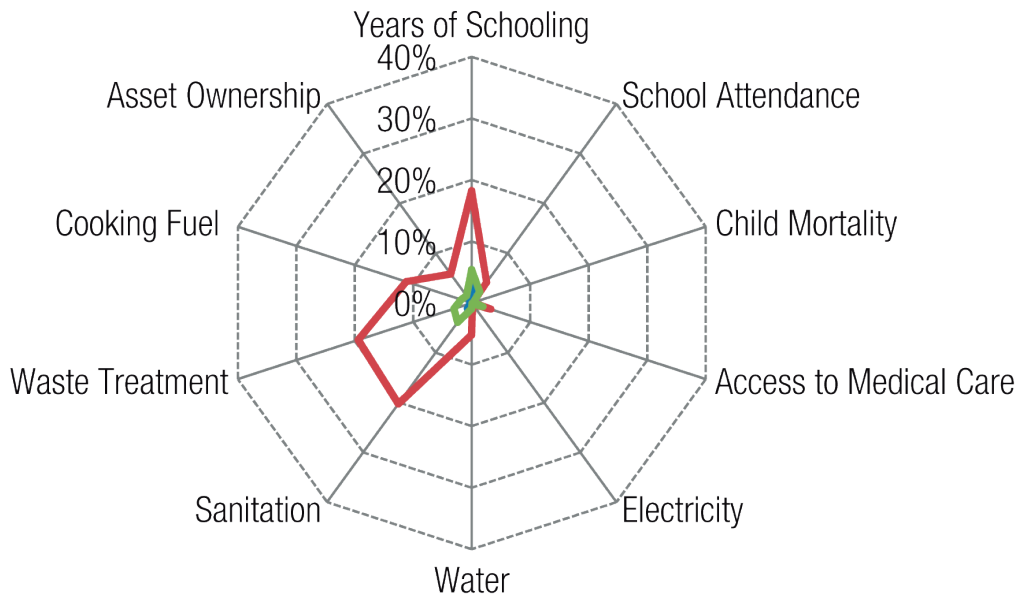

2013

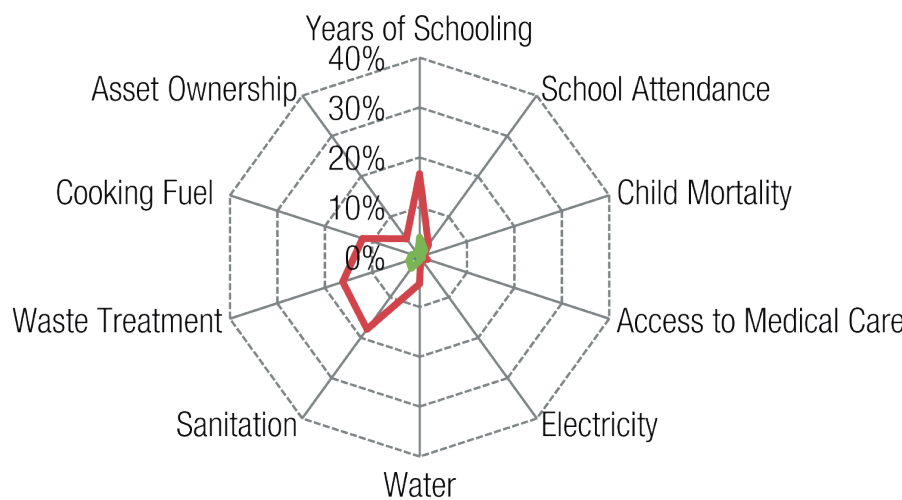

Urban

Rural

Total

Source: PAD-MG $(2009,2011,2013)$ 
Finally, it is interesting to develop a comparative analysis between the state of Minas Gerais and Brazil in terms of one-dimensional (monetary) and multidimensional indexes. The pattern of longitudinal analysis of the poverty situation allows a diagnosis to be made in terms of its temporal evolution. However, it should be noted that the differences between indexes occur due to the use of different databases, information being available in different years for Brazil and Minas Gerais as well as the use of distinct criteria for the selection of various components of the indexes and predefined cutoffs among others. In this sense, the panel presented in figure 14 only fulfills the function of identifying generic trends to better understand the recent poverty situation in the state of Minas Gerais and in Brazil.

Comparatively speaking one can note a small difference between Brazil and Minas Gerais concerning the MPI and other poverty measurements (figure 14). The national measurements date from 2006 to 2013 and Minas Gerais measurements date from 2009 to 2013. The MPI percentage in Brazil was 1,7\% and 1,9\% in 2006 and 2013, respectively. However, in Minas Gerais, in the years 2009 and 2013, the MPI measurement was 3,2\% and 1,55\%, respectively. Thereby, it may be inferred that, on average, multidimensional poverty is more pronounced in Minas Gerais in comparison with Brazil (excepted for 2013), but it is assuming a systematic reduction trend in contrast to the 2013 increase in the country mainly due to the reduction of the proportion of poor $(\mathrm{H})$. To some extent, this could be indicative of a greater impact of the policies that combat poverty in Minas Gerais than in Brazil.

When using the one-dimensional and monetary index for comparison purposes, it is noted that in Minas there is a trend of extreme poverty stability (U\$ 1.25 per day) and significant poverty reduction (U\$2.00 per day) between the years of 2009 and 2011 (data for 2013 are not available). While for Brazil the reduction and relative stability of poverty are present in the year of 2012.

From the analysis of the data of one-dimensional and multidimensional poverty, it can be inferred as well that the state of Minas Gerais is progressing more significantly in reducing the proportion of poor without altering the condition of the extremely poor. That can be explained by the relative stability of the indicator of multidimensional poverty intensity. An interesting deduction that can be drawn from these results could be that social policies in Minas Gerais are effective, but need to be better focused on the poorest.

In the last years analyzed for Brazil (one-dimensional for 2012 and multidimensional for 2013), there is a tendency to increase both extreme poverty and poverty, with relative stability of the intensity of multidimensional poverty, indicating a process of worsening of the situation of the Brazilian population.

\section{FIGURE 14 COMPARATIVE POVERTY MEASUREMENTS FOR MINAS GERAIS AND BRAZIL}

\begin{tabular}{l|c|c|c}
\hline Summary MG & $\mathbf{2 0 0 9}$ & $\mathbf{2 0 1 1}$ & $\mathbf{2 0 1 3}$ \\
\hline MPI & $3.2 \%$ & $2.30 \%$ & $1.55 \%$ \\
\hline Percentage of MPI Poor (H) & $8.33 \%$ & $6.06 \%$ & $4.00 \%$ \\
Average Intensity of Deprivation (A) & $38.94 \%$ & $37.37 \%$ & $36 \%$ \\
\hline
\end{tabular}


RAP | The transformative capacity of the Brazilian federal government in building a social welfare bureaucracy in the municipalities

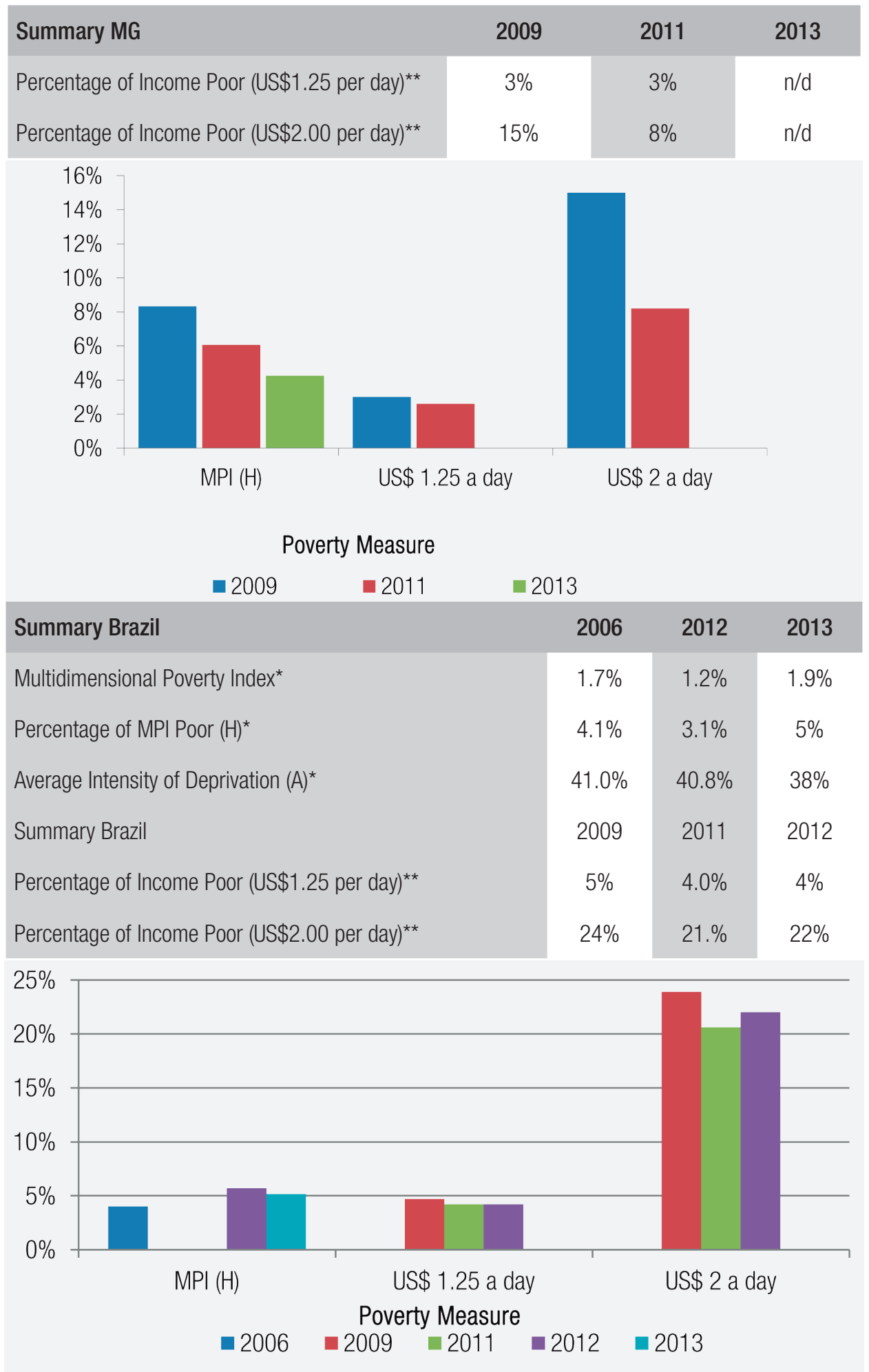

Source: IBGE (2010); PAD-MG (2009, 2011, 2013); Ophi (2012) and UNDP (2014).

${ }^{*}$ Ophi MPI 2006 and 2012.

**Ipea, 2011. 


\section{FINAL REMARKS}

Given this overview, why should the government use the multidimensional poverty measurement? In our opinion, using a multidimensional poverty analysis is beneficial because it contributes to targeting social policies that are better aimed at the poorest population, since it goes beyond addressing financial resources. The identification of each dimension and each indicator of deprivation could help the government design specific social policies that would be more efficient in solving the problems highlighted here. Hence, the multidimensional poverty analysis conducted in the state of Minas Gerais is an important strategy for guiding the conception and implementation of social policies that are likely to achieve more effective results. Due to a more comprehensive understanding of the multidimensional nature of poverty and the subsequent identification of particularly vulnerable territories, the state could develop targeted social policies that make better use of public resources.

The expectation is to expand the strategy of multidimensional analysis of poverty for the others Brazilian states, thus reaching the entire territory of Brazil. In this context, we aim to develop more assertive social policies with an effective impact on poverty indicators. That is, confronting poverty in the multidimensional perspective necessarily implies a broadening of the spectrum of poverty coping policies in addition to income increase with implementation of policies of health, education and access to social goods areas (Standard of Living). This would contribute to an innovative and flexible vision of combating poverty with a plurality of interventions in different fields of the socioeconomic conditions of vulnerable populations.

Another relevant aspect of the multidimensional poverty analysis is the possibility of incorporating other dimensions and indicators linked to the various social areas such as security, environment, housing, etc., that also contribute to the poverty situation of the population. In this way, it is feasible and interesting to customize the measurement of multidimensional poverty, making it possible to construct a situational diagnosis closer to the social reality of vulnerable populations. To some extent, this strategy could contribute to a more effective use of the scarce financial resources of Brazilian states and municipalities. Also, one can advance to analyzes of multidimensional poverty by gender, age group, social strata, among others, as well as the characteristics of acute or chronic poverty that transform this analytical perspective into a broad and accurate instrument for measuring poverty. In summary, there is a range of alternatives for using this innovative analysis of poverty that can greatly contribute to the implementation of more effective social policies.

However, the results presented here require a more precise analysis along with public debate (social participation) on the choice of dimensions and indicators for measuring the components of multidimensional poverty. With the knowledge acquired from social participation, particularly with society's considerations and beliefs regarding the concept of multidimensional poverty, it will be possible to have a clearer definition of poverty and a measurement that is closer to the social reality. 


\section{REFERENCES}

ALKIRE, Sabina; FOSTER, James. Counting and multidimensional poverty measurement. Journal of Public Economics, Oxford, v. 95, n. 7-8, p. 476-487, 2011.

ALKIRE, Sabina; SANTOS, M. Emma. Acute multidimensional poverty: a new index for developing countries. Oxford: Oxford Poverty and Human Development Initiative, 2011. (Ophi Working Papers, n. 38). Available at: <www.ophi.org.uk>. Accessed on: 10 Oct. 2016.

ALKIRE, Sabina; SANTOS, M. Emma. Brazil country briefing. Oxford: Oxford Poverty and Human Development Initiative, 2010. (Country Briefings 2011, Brazil). Available at: <www.ophi.org.uk>. Accessed on: 15 Oct. 2016.

ALKIRE, Sabina et al. Multidimensional poverty index 2011: brief methodological note. Oxford: Oxford Poverty and Human Development Initiative, 2011. Available at: <http://ophi.org.uk/wp-content/ uploads/MPI_2011_Methodology_Note_4-112011_1500.pdf >. Accessed on: 23 Nov. 2016.

BATTISTON, Diego et al. Income and beyond: multidimensional poverty in six Latin American countries. Buenos Aires: PNUD - Regional Bureau for Latin American and the Caribbean, 2009.

BRASIL. Ministério do Desenvolvimento Social e Combate a Fome. Plano Brasil sem Miséria. Brasilia, DF: MDS, 2011. Available at: <www.mds.gov.br>. Accessed on: 15 Dec. 2016.

BRASIL. Sintese de indicadores sociais. Rio de janeiro: IBGE, 2011. Available at: <www.ibge.gov. br>. Accessed on: 15 Dec. 2016.

CAMPELLO, Tereza; NERI, Marcelo. Programa Bolsa Família: uma década de inclusão e cidadania. Rio de Janeiro: Ipea, 2013.

CODES, Luiza. A trajetória do pensamento científico sobre a pobreza: em direção a uma visão complexa. Brasília, DF: Ipea, 2008. (Textos para discussão, n. 1332).

ECLAC (CEPAL). Inclusive social development: the next generation of policies for overcoming poverty and reducing inequality in Latin America and the Caribbean (LC.L/4056/Rev.1). Santiago del Chile: Eclac, 2016.
ECLAC (CEPAL). Social panorama of Latin America. Santiago do Chile: Nacion Unidas, Division de Desarrollo Social, 2013. Available at: <www.eclac. org>. Accessed on: 10 Dec. 2016.

FERES, Carlos; MANCERO, Xavier. Enfoques para la medición de la pobreza:breve revisión de la literatura. Santiago do Chile: Cepal, 2001. (Serie estudios estadísticos y prospectivos).

FJP. Diagnóstico multidimensional da pobreza rural. Belo Horizonte: Fundação João Pinheiro/Sedese, Governo de Minas Gerais, 2017. Available at: $<w w w$. fjp.mg.gov.br>. Accessed on: 10 Feb. 2018.

FJP. Perfil de Minas Gerais 2012. 15. ed. Belo Horizonte: Fundação João Pinheiro, Governo de Minas Gerais, 2012. Available at: <www.fp.mg.gov. br>. Accessed on: 27 Nov. 2016.

FJP. Plano de desenvolvimento do Vale do Jequitinhonha - PDVJ. Belo Horizonte: Fundação João Pinheiro/Sedese, Governo de Minas Gerais, 2017. Available at: <www.fjp.mg.gov.br>. Accessed on: 10 Feb. 2018.

FOSTER, James. A report on Mexican multidimensional poverty measurement. Oxford: Oxford Poverty and Human Development Initiative, 2007. (Ophi Working Papers, n. 40). Available at: <www.ophi.org.uk>. Accessed on: 15 Oct. 2016.

IBGE. Pesquisas sobre população. Brasília, DF: IBGE, 2014. Available at: <www.ibge.gov.br>. Accessed on: 20 Nov. 2016.

IPEA. A década inclusiva (2001-2011): desigualdade, pobreza e políticas de renda. Rio de Janeiro, 2012. (Comunicado do Ipea, n. 155).

IPEA. Programas de Transferências de Renda no Brasil: impactos sobre desigualdade. Rio de Janeiro: Ipea, 2012. (Textos para Discussão, n. 1228).

IPEA. Situação social nos estados: Minas Gerais. Brasília: Diretoria de Estudos e Políticas Sociais — Disoc, 2011. Available at: <www.ipea.gov.br>. Accessed on: 8 Nov. 2016.

MIDEPLAN. Ministerio de Planificación y Cooperación Chile. Síntesis de los principales enfoques, métodos y estrategias para la superación de la pobreza. Santiago do Chile: Cepal/Eclac, 2002.

MINAS GERAIS. Cadernos Travessia. Belo Horizonte: Oficina de Travessias, 2011. Available 
at: <www.scribd.com/doc/66796279/CadernoTravessia-6>. Accessed on: 15 Oct. 2016.

MINAS GERAIS . Pesquisa de amostra domiciliar do estado de Minas Gerais. Belo Horizonte: Fundação João Pinheiro, 2009. Available at: <www.fjp.mg.gov. br>. Accessed on: 10 Oct. 2016.

MINAS GERAIS . Pesquisa de amostra domiciliar do estado de Minas Gerais. Belo Horizonte: Fundação João Pinheiro, 2011. Available at: <www.fjp.mg.gov. br>. Accessed on: 10 Oct. 2016.

MINAS GERAIS . Pesquisa de amostra domiciliar do estado de Minas Gerais. Belo Horizonte: Fundação
João Pinheiro, 2013. Available at: <www.fjp.mg.gov. br>. Accessed on: 10 Oct. 2016.

PNUD. Human development report by Ophi presented the MPI of Brazil. Santiago del Chile: Regional Bureau for Latin American and the Caribbean, 2010.

SANTOS, Emma; ALKIRE, Sabina. Training material for producing national human development reports: the multidimensional index (MPI). Oxford: Poverty Oxford and Human Development Initiative, 2011. Available at: <www.ophi.org.uk $>$. Accessed on: 10 Oct. 2016.

SEN, Amartya. Desenvolvimento como liberdade. São Paulo: Schwarcz, 2000.

\section{Murilo Fahel}

$\mathrm{PhD}$ in Sociology and Politics at UFMG; Post-doctoral degree from the University of Oxford; Professor and researcher of the School of Government at João Pinheiro Foundation. E-mail: murilo.fahel@fjp.mg.gov.br.

\section{Letícia Telles}

Graduated in economics from IBMEC; Research in Fapemig (2012-2014) at the School of Government of the João Pinheiro Foundation. E-mail: leriteles@gmail.com. 


\section{ANNEX 1: CONCEPTUAL JUSTIFICATION OF THE INDICATORS}

\section{TABLE A1}

\begin{tabular}{|c|c|c|c|c|c|}
\hline Dimension & $\begin{array}{l}\text { Dimension's } \\
\text { weight }\end{array}$ & Indicator & $\begin{array}{l}\text { Indicator's } \\
\text { weight }\end{array}$ & Cutoff & Observation \\
\hline \multirow{6}{*}{$\begin{array}{l}\text { Living } \\
\text { Standards }\end{array}$} & \multirow{6}{*}{$33.33 \%$} & Electricity & $05.56 \%$ & $\begin{array}{l}\text { The household is considered } \\
\text { deprived if it does not have } \\
\text { access to electricity. }\end{array}$ & to The same as the Global MPI. \\
\hline & & $\begin{array}{l}\text { Drinking } \\
\text { Water }\end{array}$ & $05.56 \%$ & $\begin{array}{l}\text { The household is considered } \\
\text { deprived if it does not have } \\
\text { access to piped water in at least } \\
\text { one room or if the water does } \\
\text { not come from the distribution } \\
\text { network or well/spring. }\end{array}$ & $\begin{array}{l}\text { Similar to the Global MPI. } \\
\text { Nevertheless, due to lack of data } \\
\text { available, "access to piped water } \\
\text { in at least one room" was used } \\
\text { as a proxy for distances smaller } \\
\text { than } 30 \text { minutes (return). }\end{array}$ \\
\hline & & Sanitation & $05.56 \%$ & $\begin{array}{l}\text { The household is deprived if the } \\
\text { bathroom's gully is not connected } \\
\text { to the sewage or if the bathroom } \\
\text { is shared. }\end{array}$ & The same as the Global MPI. \\
\hline & & $\begin{array}{l}\text { Waste } \\
\text { Treatment }\end{array}$ & $05.56 \%$ & $\begin{array}{l}\text { The household is deprived if there } \\
\text { is no garbage collection service } \\
\text { (e.g. it is burned or dumped on } \\
\text { river). }\end{array}$ & $\begin{array}{l}\text { This variable substitutes } \\
\text { "resident flooring" so that } \\
\text { the index more accurately } \\
\text { represents the realities and } \\
\text { challenges in Brazil. }\end{array}$ \\
\hline & & $\begin{array}{l}\text { Cooking } \\
\text { Fuel }\end{array}$ & $05.56 \%$ & $\begin{array}{l}\text { The household is deprived if it } \\
\text { cooks with wood, charcoal or } \\
\text { dung. }\end{array}$ & The same as the Global MPI. \\
\hline & & $\begin{array}{c}\text { Asset } \\
\text { Ownership }\end{array}$ & $05.56 \%$ & $\begin{array}{l}\text { The household is deprived if it } \\
\text { does not have more than } 1 / 3 \text { of } \\
\text { the items required (land line; cell } \\
\text { phone; television; stove; fridge, } \\
\text { freezer; desktop computer; laptop } \\
\text { computer; bicycle) and does not } \\
\text { have car or motorbike. }\end{array}$ & $\begin{array}{l}\text { Similar to the Global MPI. } \\
\text { Nevertheless, due to the lack } \\
\text { of available data and also to } \\
\text { more adequately represent the } \\
\text { realities and challenges in Brazil, } \\
\text { minor changes were made. It } \\
\text { was decided that the residence } \\
\text { should have e more than } 3 \\
\text { out of the } 9 \text { items required } \\
(1 / 3) \text { instead of } 1 \text { out of } 6 \\
(1 / 6 \text { - Global MPI) of the items } \\
\text { required. In addition, and the } \\
\text { motorbike replaced the tractor. }\end{array}$ \\
\hline
\end{tabular}




\begin{tabular}{|c|c|c|c|c|c|}
\hline Dimension & $\begin{array}{l}\text { Dimension's } \\
\text { weight }\end{array}$ & Indicator & $\begin{array}{l}\text { Indicator's } \\
\text { weight }\end{array}$ & Cutoff & Observation \\
\hline \multirow[t]{3}{*}{ Education } & \multirow[t]{2}{*}{$33.33 \%$} & $\begin{array}{l}\text { Years of } \\
\text { Schooling }\end{array}$ & $16.67 \%$ & $\begin{array}{l}\text { The household is considered } \\
\text { deprived if none of the members, } \\
16 \text { or older , have completed } 9 \\
\text { years of schooling (completed } \\
\text { primary school). }\end{array}$ & $\begin{array}{l}\text { Differs from the Global MPI as } \\
\text { it considers } 9 \text { years instead } \\
\text { of } 5 \text { (constitutes all of primary } \\
\text { schooloing with the first stage of } \\
5 \text { years and second of } 4 \text { ). }\end{array}$ \\
\hline & & $\begin{array}{c}\text { School } \\
\text { Attendance }\end{array}$ & $16.67 \%$ & $\begin{array}{l}\text { The household is considered } \\
\text { deprived if at least one member, } \\
\text { between the ages of } 6 \text { and } 17 \text {, } \\
\text { is not enrolled in school. }\end{array}$ & $\begin{array}{l}\text { Differs from the Global MPI, as } \\
\text { it considers } 9 \text { years of primary } \\
\text { school (years } 1 \text { to } 9 \text { ) and } 3 \text { years } \\
\text { of high school (years } 1 \text { to } 3 \text { ). }\end{array}$ \\
\hline & \multirow[b]{2}{*}{$33.33 \%$} & $\begin{array}{l}\text { Child } \\
\text { Mortality }\end{array}$ & $16.67 \%$ & $\begin{array}{l}\text { The household is considered } \\
\text { deprived if any child, } \mathbf{5} \text { years or } \\
\text { younger, has died. }\end{array}$ & $\begin{array}{l}\text { Proxy: There is no variable } \\
\text { that includes all infant deaths. } \\
\text { The number of deaths used } \\
\text { corresponds to the last child } \\
\text { born within the past } 5 \text { years. }\end{array}$ \\
\hline Health & & $\begin{array}{l}\text { Access to } \\
\text { Health Care }\end{array}$ & $16.67 \%$ & $\begin{array}{l}\text { The household is considered } \\
\text { deprived if at least one member } \\
\text { has needed health care and has } \\
\text { not been taken care of by an } \\
\text { adequate professional or has not } \\
\text { been taken care of because of } \\
\text { barriers to health services, both } \\
\text { within the last month. }\end{array}$ & $\begin{array}{l}\text { This variable depends on } \\
\text { personal perception. } \\
\text { Due to the lack of the data } \\
\text { available, the nutrition index } \\
\text { has been replaced. }\end{array}$ \\
\hline
\end{tabular}

Source: Elaborated by the authors. 